\title{
Investigation of a deep ice core from the Elbrus western plateau, the Caucasus, Russia
}

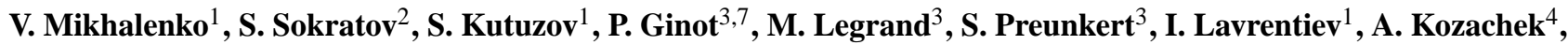 \\ A. Ekaykin ${ }^{4,6}$, X. Faïn ${ }^{3}$, S. Lim ${ }^{3,9}$, U. Schotterer ${ }^{5, *}$, V. Lipenkov ${ }^{4}$, and P. Toropov ${ }^{1,8}$ \\ ${ }^{1}$ Institute of Geography, Russian Academy of Sciences, Moscow, Russia \\ ${ }^{2}$ Arctic Environment Laboratory, Faculty of Geography, Lomonosov Moscow State University, Moscow, Russia \\ ${ }^{3}$ Univ. Grenoble Alpes, CNRS - UMR5183, Laboratoire de Glaciologie et Géophysique de l'Environnement (LGGE), \\ Grenoble, France \\ ${ }^{4}$ Arctic and Antarctic Research Institute, St. Petersburg, Russia \\ ${ }^{5}$ Climate and Environmental Physics Group, University of Bern, Bern, Switzerland \\ ${ }^{6}$ St. Petersburg State University, St. Petersburg, Russia \\ ${ }^{7}$ Observatoire des Sciences de l'Univers de Grenoble, IRD UMS222, CNRS, Université Joseph Fourier Grenoble 1, \\ Saint Martin d'Héres, France \\ ${ }^{8}$ Department of Meteorology and Climatology, Faculty of Geography, Lomonosov Moscow State University, Moscow, Russia \\ ${ }^{9}$ Department of Earth and Environmental Sciences, Korea University, Seoul, South Korea \\ * retired
}

Correspondence to: V. Mikhalenko (mikhalenko@hotmail.com)

Received: 19 April 2015 - Published in The Cryosphere Discuss.: 16 July 2015

Revised: 14 October 2015 - Accepted: 5 November 2015 - Published: 4 December 2015

\begin{abstract}
A $182 \mathrm{~m}$ ice core was recovered from a borehole drilled into bedrock on the western plateau of Mt. Elbrus $\left(43^{\circ} 20^{\prime} 53.9^{\prime \prime} \mathrm{N}, 42^{\circ} 25^{\prime} 36.0^{\prime \prime} \mathrm{E}\right.$; $5115 \mathrm{~m}$ a.s.1.) in the Caucasus, Russia, in 2009. This is the first ice core in the region that represents a paleoclimate record that is practically undisturbed by seasonal melting. Relatively high snow accumulation rates at the drilling site enabled the analysis of the intraseasonal variability in climate proxies. Borehole temperatures ranged from $-17^{\circ} \mathrm{C}$ at $10 \mathrm{~m}$ depth to $-2.4{ }^{\circ} \mathrm{C}$ at $182 \mathrm{~m}$. A detailed radio-echo sounding survey showed that the glacier thickness ranged from $45 \mathrm{~m}$ near the marginal zone of the plateau up to $255 \mathrm{~m}$ at the glacier center. The ice core has been analyzed for stable isotopes $\left(\delta^{18} \mathrm{O}\right.$ and $\left.\delta \mathrm{D}\right)$, major ions $\left(\mathrm{K}^{+}, \mathrm{Na}^{+}, \mathrm{Ca}^{2+}, \mathrm{Mg}^{2+}, \mathrm{NH}_{4}^{+}, \mathrm{SO}_{4}^{2-}, \mathrm{NO}_{3}^{-}, \mathrm{Cl}^{-}\right.$, $\left.\mathrm{F}^{-}\right)$, succinic acid $\left(\mathrm{HOOCCH} \mathrm{COOH}_{2} \mathrm{COO}\right.$, and tritium content. The mean annual net accumulation rate of $1455 \mathrm{~mm}$ w.e. for the last 140 years was estimated from distinct annual oscillations of $\delta^{18} \mathrm{O}, \delta \mathrm{D}$, succinic acid, and $\mathrm{NH}_{4}^{+}$. Annual layer counting also helped date the ice core, agreeing with the absolute markers of the tritium 1963 bomb horizon located at the core depth of $50.7 \mathrm{mw}$.e. and the sulfate peak of the
\end{abstract}

Katmai eruption (1912) at $87.7 \mathrm{mw}$.e. According to mathematical modeling results, the ice age at the maximum glacier depth is predicted to be $\sim 660$ years BP. The 2009 borehole is located downstream from this point, resulting in an estimated basal ice age of less than 350-400 years BP at the drilling site. The glaciological and initial chemical analyses from the Elbrus ice core help reconstruct the atmospheric history of the European region.

\section{Introduction}

Understanding climate change, regional environmental patterns, and predicting future impacts are currently some of the most important scientific challenges. The Earth's climate system has a profound influence on society and human prosperity. Discriminating human-induced and natural climate variability is an urgent task and cannot be solved by only using short instrumental meteorological observations or climate modeling experiments. Proxy records such as lake and marine sediments, ice cores, tree rings, and corals can extend 
the instrumental climatic records. Some proxies have seasonal to annual resolution, and can be combined into large networks covering continental and even global scales. Individual proxies can be calibrated with instrumental data, resulting in time series appropriate for statistical analyses and numerical modeling. Due to both the urgency of climate change, and our increased ability to synthesize paleoclimate data with future projections, it is essential to have reliable regional paleoclimate reconstructions for the last millennia (Vaughan et al., 2013). The study of chemical impurities in glacier snow and ice permits the reconstruction of our changing atmosphere from the pre-industrial era to present-day (see Legrand and Mayewski, 1997, for a review).

Ice cores from polar glaciers that result in multi-millennial records due to minimal disturbance by melt/refreeze processes are presently considered to be the best representation of past climate conditions at hemispheric scales. However, calculations based on observational data trends in the major climatic characteristics show highly pronounced regional variability. Such variability is reproduced by modern climate models and can be projected into the future (AMAP, 2011), but the reliability of the simulations depends on the amount and the quality of existent data, and some of the results such as the precipitation rate are questionable (Anisimov and Zhil'tsova, 2012).

The need for regional paleoclimate records from non-polar areas has led to the development of numerous reconstructions of annual and seasonal resolution based on instrumental climate data and paleoclimate proxies. Ice cores from low and mid-latitude high mountain glaciers can reconstruct past atmospheric conditions in areas with long human histories. A number of studies examined climate and environmental changes in various non-polar areas (Vimeux et al., 2009; Thompson, 2010) including the European Alps (Barbante et al., 2004; Preunkert and Legrand, 2013; Schwikowski, 2004), the continental Siberian Altai (Eichler et al., 2011), and Kamchatka (Kawamura et al., 2012; Sato et al., 2014).

Climate records located in the region of interest often best represent the climate variability from the region itself. Despite their temporal length and their continuous records, the Greenland and Antarctic ice-core data are from sites that are very remote from most inhabited areas. Therefore, the comparable paleoclimate records derived directly from glaciers in Europe and Asia are highly valuable. However, seasonal melting and water infiltration distort the climate proxies recorded in firn and ice even at high altitudes in the Andes (Ginot et al., 2010), Himalayas (Hou et al., 2013) and the low latitudes of the Arctic islands (Kotlyakov et al., 2004).

The documented conditions (Tushinskii, 1968; Mikhalenko, 2008) near the top of Mt. Elbrus suggest the possibility of a reasonably long climatic record in an ice core not affected by meltwater infiltration. Relatively high accumulation on the western plateau (Mikhalenko et al., 2005) assures high temporal resolution of the ice-core data with the possibility of seasonal variations in the analyt- ical results (Werner et al., 2000). Due to this combination of factors, we were motivated to recover ice cores from the western plateau of Mt. Elbrus to obtain natural archives that preserve environmental data associated with atmospheric chemistry, dust deposition, biomass burning, anthropogenic emission, and climate change in the Caucasus (Mikhalenko, 2010). The aim of the Elbrus drilling project is to reconstruct past climate and environmental changes for the Caucasian region from the ice core. Here, we provide an overview of the existing geographical, glaciological, meteorological, and climatological knowledge from the region, and then focus on the glaciological and glacio-chemical characterization of a new drilling site located on the western plateau of Mt. Elbrus. We use stable isotopes, glacial-chemical records and simplified thermomechanical modeling to create a chronology for the $182 \mathrm{~m}$ Elbrus ice core. Finally, we present the possibilities to develop the high-resolution regional paleoclimate reconstruction from this ice core.

\section{Previous investigations of the Caucasus and Elbrus}

\subsection{Geographical and glaciological characteristics of the Caucasus region}

The Caucasus are situated between the Black and the Caspian seas, and generally trend east-southeast, with the Greater Caucasus range often considered as the divide between $\mathrm{Eu}-$ rope and Asia. The glaciers in the Caucasus cover an area of around $1121 \pm 30 \mathrm{~km}^{2}$ (Kutuzov et al., 2015) (Fig. 1).

Glacier studies in the Caucasus began more than 100 years ago and mainly focused on glacier mapping (Pastukhov, 1893; Podozerskii, 1911) or reconstructing past glacier positions by geomorphological methods (Abich, 1874; Mushketov, 1882; Kovalev, 1961; Serebryannyi et al., 1984). Records of contemporary glaciological processes were obtained during the International Geophysical Year (IGY) in 1957-1959 (Tushinskii, 1968) when the climatic conditions of the glacial zone, accumulation and ablation of the glaciers, glacier runoff, glacier ice formation zones, and snow and firn stratigraphy were investigated. These studies were mainly conducted on the southern slope of Elbrus extending from the glacier tongue to the summit (Fig. 1b), and determined that surface snowmelt did not occur above $5000 \mathrm{~m}$ (Troshkina, 1968). Complex studies of mass, water, and the heat balance of glaciers in the Caucasus were started during the International Hydrological Decade (1964-1974) (Golubev et al., 1978; Dyurgerov and Popovnin, 1988; Krenke et al., 1988). A number of studies examined fluctuations in glacier dimensions and volume (Stokes et al., 2006; Kutuzov et al., 2012, 2015; Nosenko et al., 2013, Shahgedanova et al., 2014), glacier mass balance (Rototaeva and Tarasova, 2000), and regional snow chemistry (Kerimov et al., 2011). Characteristics of the mineral dust and its source were inves- 

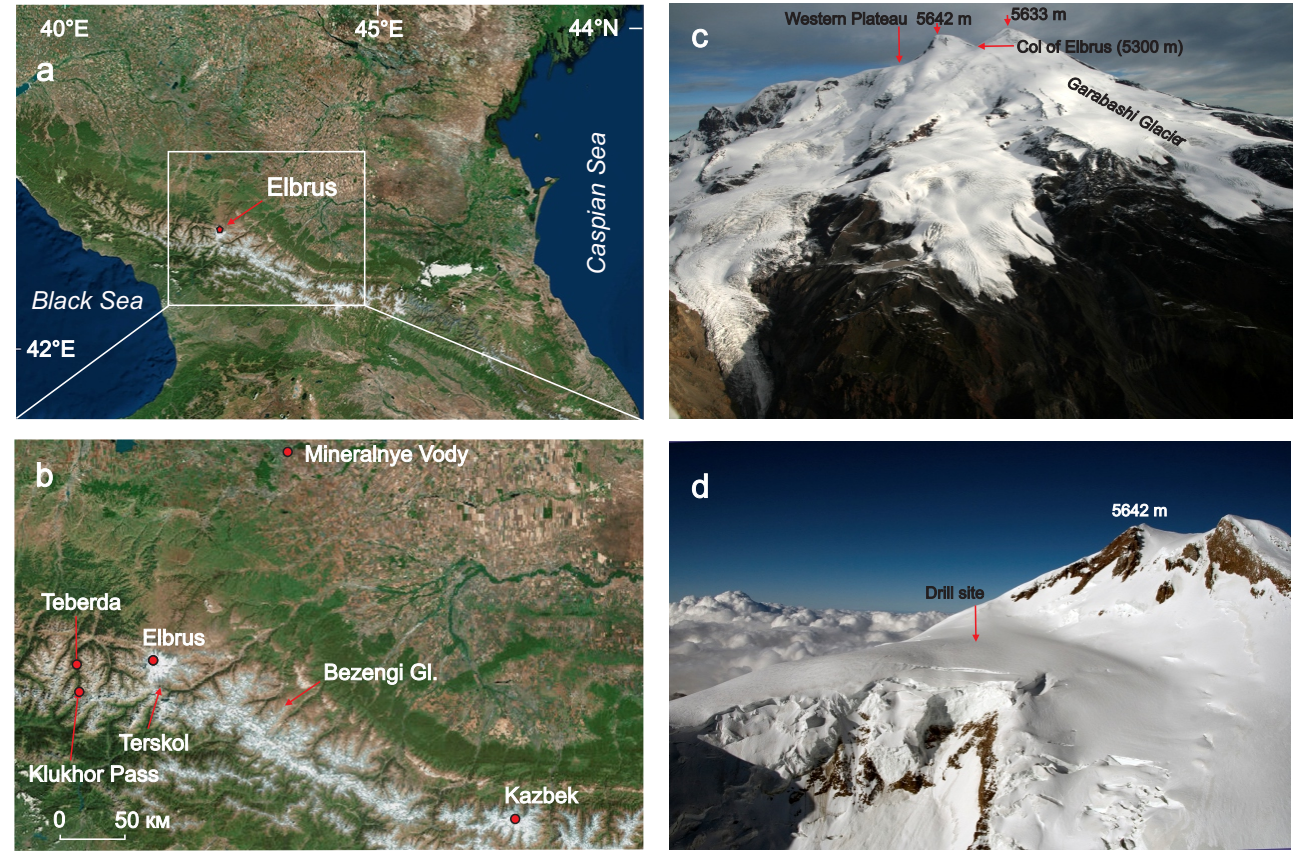

Figure 1. Location of study area: (a) Mt. Elbrus in the Caucasus; (b) glaciers and meteorological stations; (c) Mt. Elbrus from the south demonstrating the position of the western plateau; (d) western Elbrus plateau drill site (photos by I. Lavrentiev, September 2009). ArcGIS World Imagery Basemap used as the background. Source: DigitalGlobe.

tigated using records of shallow ice cores and snow pits from Elbrus (Kutuzov et al., 2013; Shahgedanova et al., 2013).

In addition to the glaciological studies, multiple tree-ringbased reconstructions represent mean summer air temperature, river runoff, and glacier mass balance in the region (Dolgova et al., 2013; Solomina et al., 2012). The first regional lake sediment cores retrieved in 2010, 2012, and 2013 demonstrate an excellent potential for using lacustrine records to study long-term climate and glacier history variations (Solomina et al., 2013).

Despite the substantial glacier area in the Caucasus, few suitable sites for ice-core research exist due to the relatively low elevation and considerable surface melt below $5000 \mathrm{~m}$. Several shallow and intermediate depth ice cores have been recovered at the Caucasus glaciers (Golubev et al., 1988; Zagorodnov et al., 1992; Bazhev et al., 1998), but these previous studies were conducted at sites where considerable meltwater percolation smoothed isotopic and geochemical profiles. However, the vast high-elevation plateaus on the glaciers of Elbrus (5642 m), Kazbek (5033 m), and Bezengi $(\sim 5000 \mathrm{~m})$ (see Fig. $1 \mathrm{~b})$ present promising sites for obtaining ice-core records.

\subsection{Geographical and glaciological characteristics of Elbrus}

Elbrus, the highest summit of the Caucasus, has two peaks at its highest elevations with both an eastern (5621 m a.s.l.) and western (5642 $\mathrm{m}$ a.s.l.) summit where the whole complex is covered by glaciers with a total area of $120 \mathrm{~km}^{2}$ (Zolotarev and Khar'kovets, 2012) (Fig. 1). Elbrus is an active volcano but only minor fumarole activity is currently observed (Laverov et al., 2005).

Glaciers on Elbrus are situated in the altitudinal range of 2800 to $5642 \mathrm{~m}$. Stratigraphic records display several ice formation zones on Mt. Elbrus (Bazhev and Bazheva, 1964; Psareva, 1964; Troshkina, 1968). The coldest conditions occur above $5200 \mathrm{~m}$ a.s.l., where the mean summer air temperature does not exceed $0{ }^{\circ} \mathrm{C}$, while the Elbrus glaciers between 4700 and $4900 \mathrm{~m}$ a.s.l. have limited surface melt. Ice lenses up to $30 \mathrm{~cm}$ thick alternate with firn horizons in the uppermost snow and firn at $5050 \mathrm{~m}$ a.s.l. (Mikhalenko, 2008). Snow accumulation measurements from 1985 and 1988 demonstrate total snow accumulation of 400-600 $\mathrm{mm}$ w.e. $\mathrm{a}^{-1}$ with considerable wind-driven snow erosion at the col of Elbrus (5300 ma.s.l.; Fig. 1c). The snow/firn temperature measured at a depth of $6 \mathrm{~m}$ was $-14{ }^{\circ} \mathrm{C}$ at the col, indicating absence of meltwater runoff from this zone.

Long-term (1983 to present) mass-balance records of Garabashi Glacier show negative values for the period since 1994. Extremely high summer temperatures and glacier melting accompany this negative trend. Garabashi Glacier surface elevation has thinned by $3.2 \mathrm{~m}$ over the last decade near the equilibrium line (Nosenko et al., 2013).

A $76 \mathrm{~m}$ long ice core was recovered in the accumulation area of the Garabashi Glacier at 3950 m a.s.l. in 1988 
(Zagorodnov et al., 1992). The firn in this ice core completely transformed into ice as a result of meltwater refreezing at 23$24 \mathrm{~m}$ depth. Thus, the geochemical profiles obtained from the ice core were smoothed by meltwater percolation and could not be used for paleoclimate and environmental reconstruction.

The next ice core drilled in this region was recovered on the western plateau of Elbrus, at $5115 \mathrm{~m}$ a.s.l. (Fig. 1). The plateau area is $\sim 0.5 \mathrm{~km}^{2}$ and is bordered to the south and southeast by two lava ridges, and by a vertical wall of Mt. Elbrus to the east. The first ice-core drilling campaign during 4-6 July 2004 resulted in a $21.4 \mathrm{~m}$ ice core with associated borehole temperature and glacier thickness measurements (Mikhalenko et al., 2005). The $10 \mathrm{~m}$ depth temperature of $-17{ }^{\circ} \mathrm{C}$ indicated that any meltwater refreezes at only a few centimeters below the surface and thus isotopic and soluble ions profiles are preserved. Ice-core records of this first shallow ice core indicated good preserved seasonal stable isotopic $\left(\delta^{18} \mathrm{O}\right.$ and $\left.\delta \mathrm{D}\right)$ oscillations and mean annual accumulation rates of approximately $1200 \mathrm{~mm}$ w.e.

\subsection{Climatology of the Caucasus and Elbrus}

The summer atmospheric circulation pattern in the Caucasus is dominated by the subtropical high pressure to the west and the Asian depression in the east. In the winter, circulation is affected by the western extension of the Siberian High (Volodicheva, 2002). The Caucasus are located in the southern section of the vast Russian Plain and are therefore buffeted by the unobstructed passage of cold air masses from the north. High elevation ridges in the southern Caucasus deflect air flowing from the west and southwest. The influence of the free atmosphere on the Elbrus glacier regime is significantly larger than local orographic effects as the glacier accumulation area lies above main ridges.

Most of the annual precipitation occurs in the western and southern sections of the Caucasus, reaching $3240 \mathrm{~mm} \mathrm{a}^{-1}$ at Achishkho weather station $(1880 \mathrm{~m})$. Precipitation ranges between 2000 and $2500 \mathrm{mma}^{-1}$ at $2500 \mathrm{~m}$ a.s.l. in the west and declines to $800-1150 \mathrm{~mm} \mathrm{a}^{-1}$ in the east on the northern slope of the Caucasus. Precipitation ranges from 3000$3200 \mathrm{~mm} \mathrm{a}^{-1}$ in the west to $1000 \mathrm{mma}^{-1}$ in the east for the southern macroslope. The proportion of winter precipitation (October-April) also declines eastward from more than 50 to $35-40 \%$ for the northern Greater Caucasus and from 60-70 to $50-55 \%$ for the southern slope (Rototaeva et al., 2006). The proportion of solid precipitation increases with altitude and reaches $100 \%$ above $4000-4200 \mathrm{~m}$. The altitude of the glacier equilibrium line (ELA), tends to increase from 2500$2700 \mathrm{~m}$ in the Belaya, Laba, and Mzymta river basins in the west to 3700-3950 m in the Samur and Kusurchay basins in the eastern sector of the northern macroslope of the Caucasus.

Mean summer (May-September) air temperature at the ELA ranges from $6-7^{\circ} \mathrm{C}$ in the west to $1-2^{\circ} \mathrm{C}$ in the east.
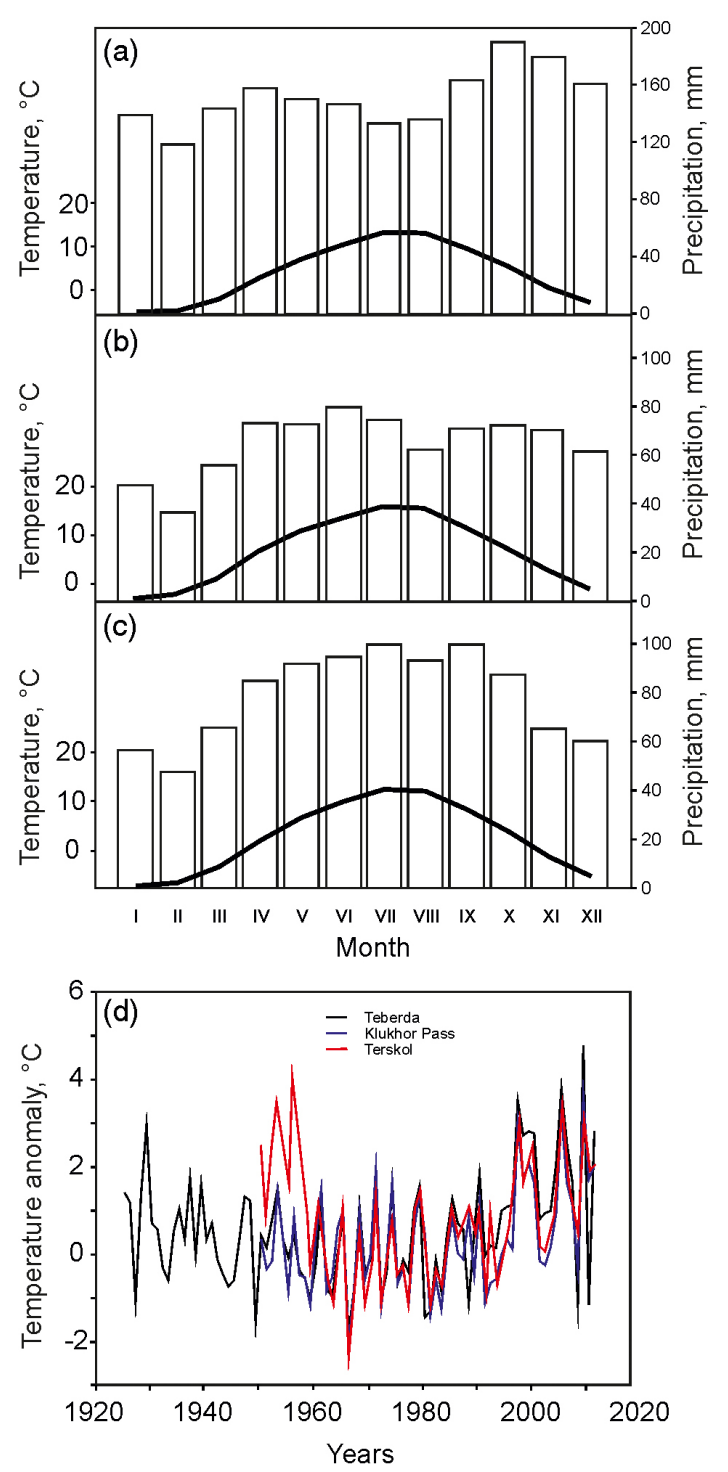

Figure 2. Mean monthly air temperature and precipitation at the Klukhor Pass (a), Teberda (b), and Terskol (c) meteorological stations and (d) anomalies of mean summer temperature with deviations from the mean 1961-1990 value.

The ELA is much higher on the glaciers of the northern macroslope, especially in the central Caucasus, where the ELA on the northern slope of Elbrus is $1000 \mathrm{~m}$ higher than on Svanetia glaciers $80 \mathrm{~km}$ southward. The number of highelevation meteorological stations is very limited in the Caucasus. Figure 2 shows the mean monthly air temperature and precipitation at the Klukhor Pass, Teberda, and Terskol meteorological stations in the western and central Caucasus (Fig. 1, Table 1).

Air temperatures at these stations are in good agreement and correlate well with lowland stations $(r=0.7-0.9$, $p<0.01$ ), indicating the homogeneity of the temperature regime for the investigated area (Solomina et al., 2012). Vari- 
Table 1. Meteorological data used in this work (modified from Solomina et al., 2012).

\begin{tabular}{llll}
\hline $\begin{array}{l}\text { Meteorological } \\
\text { station }\end{array}$ & $\begin{array}{l}\text { Geographical } \\
\text { coordinates }\end{array}$ & $\begin{array}{l}\text { Altitude, } \\
\mathrm{m}\end{array}$ & $\begin{array}{l}\text { Beginning } \\
\text { of observation }\end{array}$ \\
\hline Klukhor Pass & $43^{\circ} 15^{\prime} \mathrm{N}, 41^{\circ} 50^{\prime} \mathrm{E}$ & 2047 & 1956 \\
Teberda & $43^{\circ} 27^{\prime} \mathrm{N}, 41^{\circ} 44^{\prime} \mathrm{E}$ & 1313 & 1956 \\
Terskol & $43^{\circ} 15^{\prime} \mathrm{N}, 42^{\circ} 30^{\prime} \mathrm{E}$ & 2214 & 1951 \\
Mineralnye Vody & $44^{\circ} 14^{\prime} \mathrm{N}, 43^{\circ} 04^{\prime} \mathrm{E}$ & 316 & 1955 \\
\hline
\end{tabular}

ations in mean annual and monthly temperatures for the Klukhor Pass station for the period of observation (see Table 1) do not display a statistically significant trend. A positive trend for mean annual temperature $(r=0.33, p<0.05)$ and a slight positive trend for summer temperature occur at the Teberda station. Temperature records from the Terskol station located $7 \mathrm{~km}$ southward from the Elbrus glaciers show a negative mean annual temperature trend for the whole period of observation $(r=-0.35, p<0.05)$ (Solomina et al., 2012) but mean summer (May-September) temperatures increased from $11.5^{\circ} \mathrm{C}$ in the $1987-2001$ period to $12.0^{\circ} \mathrm{C}$ over the last decade. Winter precipitation increased by $20 \%$ over the same period, while summer precipitation did not show any change (Nosenko et al., 2013).

The first meteorological measurements were taken on the Elbrus glaciers in 1934-1935 by an expedition of the USSR Academy of Sciences (Baranov and Pokrovskaya, 1936). Air temperatures, pressure, humidity, wind regime, and incoming solar radiation have been measured at four sites from Terskol at $2214 \mathrm{~m}$ a.s.l. to the col of Elbrus at $5300 \mathrm{~m}$. A permanent meteorological station was established near Priyut- 9 on the southern slope of the Garabashi Glacier at $4200 \mathrm{~m}$ a.s.l. in 1934. 1949-1952 data demonstrate a mean annual air temperature of $-9.2^{\circ} \mathrm{C}$. The temperature of the coldest month (January) was $-17.1^{\circ} \mathrm{C}$, while the July temperature was $-0.5^{\circ} \mathrm{C}$. The minimum air temperature of $-36.1^{\circ} \mathrm{C}$ was measured on 30 January 1950 , with a maximum of $10.7^{\circ} \mathrm{C}$ on 1 August 1950. An annual precipitation rate of $1128 \mathrm{~mm}$ was observed for 1949-1952. The summer months (AprilOctober) contribute $75 \%$ of the total precipitation, while the winter months (November-March) account for only $25 \%$ (Matyukhin, 1960). The maximum wind speed at Priyut-11 station of $56 \mathrm{~m} \mathrm{~s}^{-1}$ was measured in January 1952.

During the IGY (1957-1959) the permanent all-year meteorological station was established on the glacier base on the southern slope of the Elbrus at $3700 \mathrm{~m}$ a.s.l. Meteorological records from this site include diurnal air pressure and temperature, precipitation, humidity, cloudiness, wind regime, and snow cover thickness (Tushinskii, 1968). Heat balance, air temperatures and wind speed were recorded during occasional observations in the col of Mt. Elbrus $(5300 \mathrm{~m})$. The first accumulation and ablation measurements on the southern slope of Mt. Elbrus were done during the IGY and in 1961-1962 (Bazhev and Bazheva, 1964).

\section{The western Elbrus plateau glacier archive}

In the following section we will present recent meteorological, glaciological, and glacio-chemical investigations conducted on the western Elbrus glacier plateau with the aim of obtaining knowledge about the suitability of this site to obtain relevant atmospheric ice-core records.

\subsection{On-site meteorological measurements}

An automatic weather station (AWS) from AANDERAA Data Instruments was installed on the western Elbrus plateau at $5115 \mathrm{~m}$ a.s.l. at the drill site in 2007 . The AWS was working between 30 July 2007 and 11 January 2008, but disappeared afterwards under unascertained circumstances. Here we discuss records until 12 October 2007, comprising the period with uninterrupted, consistent data. Air temperature, wind speed and direction, humidity, air pressure, radiation balance, and snow cover thickness have been measured with a time resolution of $1 \mathrm{~h}$. According to AWS records, mean daily air temperatures were negative during the period of observations. Hourly averaged temperatures were also negative, while the maximum un-averaged air temperatures were recorded on eight occasions and ranged from 0.1 to $3.1^{\circ} \mathrm{C}$. Mean hourly averaged wind speed on the drilling site was $2.9 \mathrm{~m} \mathrm{~s}^{-1}$ throughout the entire period of observation. Wind gusts up to $21.4 \mathrm{~m} \mathrm{~s}^{-1}$ were observed when fonts passed the station while the mean daily maximum wind speed was $6.7 \mathrm{~m} \mathrm{~s}^{-1}$ in August-September 2007. Our data did not cover the whole year but according to measurements from 1961 to 1962 , the average wind speed was approximately $30 \%$ higher in the winter on the southern slope of Elbrus (Tushinskii, 1968). A combination of high snow accumulation and the relatively low average wind speed from the prevailing westerlies allows us to assume that most of the precipitation did not move far from its depositional site and was not scoured by wind.

AWS records were compared with measurements from the mountain meteorological station Klukhor Pass (2037 m a.s.l.; $50 \mathrm{~km}$ westward) and the lowland Mineralnye Vody station (316 ma.s.l.; $120 \mathrm{~km}$ northeastward) (Table 1) as well as with the 20th Century Reanalysis V2 data provided by the NOAA/OAR/ESRL PSD, Boulder, Colorado, USA, (http: //www.esrl.noaa.gov/psd/) (Fig. 3a, b). A temperature lapse rate of $0.6^{\circ}$ per $100 \mathrm{~m}$ elevation was observed during the summer months. In winter, however, the lapse rate decreases due to temperature inversions at the Mineralnye Vody station. There is a good agreement between the temporal variations of mean daily air temperature measured by the AWS at the drill site, and evident in the data of 20th Century Reanalysis and other meteorological stations $(r>0.85)$. Therefore the temperature variations at the West Elbrus plateau are consistent with the regional temperature regime.

In June 2013 we conducted meteorological observations on the western Elbrus plateau near the 2009 drilling site with 

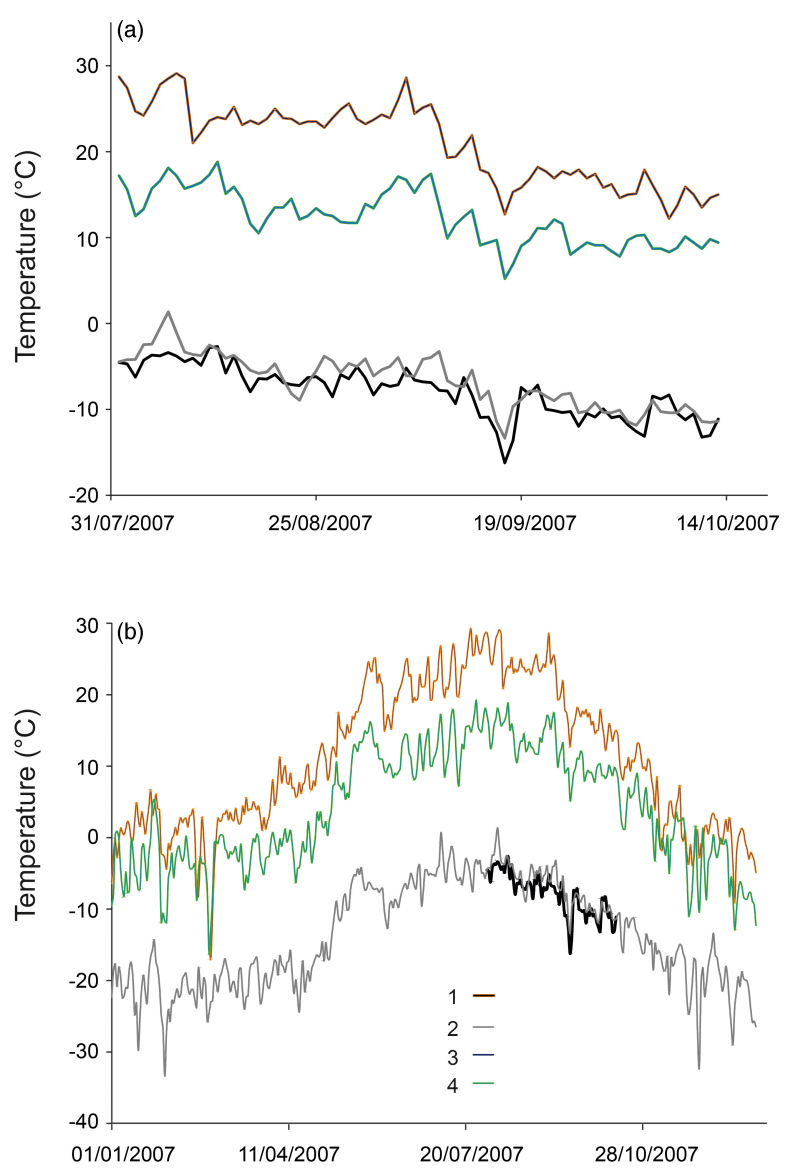

Figure 3. Daily temperature means $\left(T,{ }^{\circ} \mathrm{C}\right)$ for the periods of 1 August-12 October 2007 (a) and 1 January-31 December 2007 (b): 1 - AWS at the western Elbrus plateau; 2 - 20th Century Reanalysis V2; 3 - Mineralnye Vody meteorological station; 4 Klukhor Pass station.

an AWS DAVIS Vantage Pro 2 including air temperature, humidity, and wind speed at 0.5 and $2.0 \mathrm{~m}$, with $15 \mathrm{~min}$ resolution (Figs. 1, 4). Along with the estimation of eddy flux of heat and moisture, we measured the fluxes of total, scattered, and reflected radiation. Meteorological conditions during the observation period encompassing the maximum insolation at the summer solstice were close to mean annual parameters. Downward short-wave radiation varied between 1 and $1.2 \mathrm{~kW} \mathrm{~m}^{-2}$ which is $73-88 \%$ of the solar constant at the outer boundary of the atmosphere and 78-93\% of total insolation at $43^{\circ} \mathrm{N}$ latitude during that time of year. Albedo has a dominant role in the short-wave radiation balance. Mean albedo values of 0.66 were measured at the plateau in June 2013.

Initial measurements of radiation balance were conducted in Elbrus in 1968-1960 and showed that downward short wave radiation ranged from $1.1 \mathrm{~kW} \mathrm{~m}^{-2}$ at an elevation of $3750 \mathrm{~m}$ a.s.l. up to $1.2 \mathrm{~kW} \mathrm{~m}^{-2}$ at $5300 \mathrm{~m}$ a.s.l. (Tushinskii, 1968). Despite the negative air temperatures, the radiation
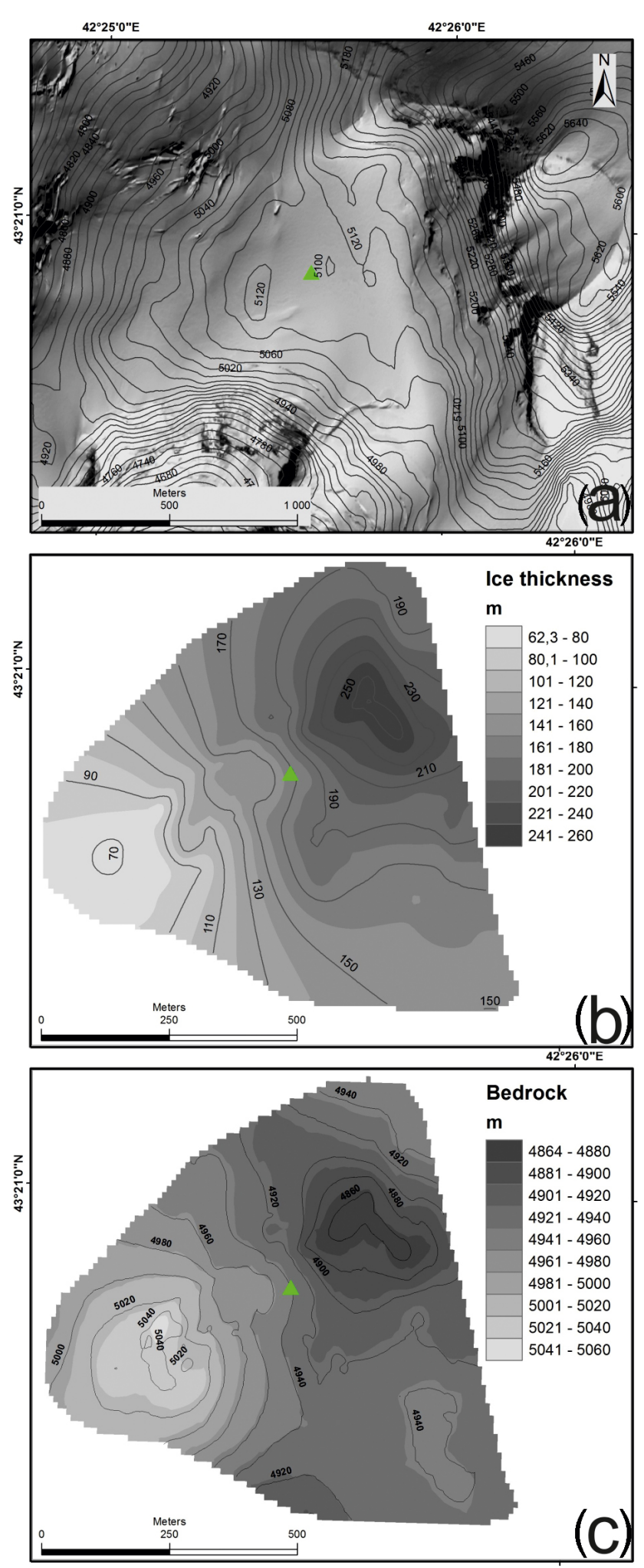

Figure 4. Glacier surface (a), ice thickness (b), and bedrock relief (c) on the western Elbrus plateau. The green triangle marks the position of the drilling site. 
balance was positive except for during the night. The mean value of the radiation balance encompassing both short-wave and long-wave radiation was $150 \mathrm{~W} \mathrm{~m}^{-2}$, affecting surface melt and snow recrystallization.

\subsection{Ground-based survey: surface topography and radar sounding}

Detailed measurements of ice thickness were carried out in 2005 and 2007 using the monopulse ice-penetrating radar VIRL with a central frequency of $20 \mathrm{MHz}$ (Vasilenko et al., 2002, 2003). VIRL ice-penetrating radar consists of a transmitter, receiver, and digital recording system with GPS. In order to synchronize the transmitter and receiver, we used a special radio channel with a repetition rate of $20 \mathrm{MHz}$. We modified the advanced VIRL-6 radar with an optical channel in 2007 (Berikashvili et al., 2006) allowing simultaneous recording and controlling. The time interval ranged between 1 and $99 \mathrm{~s}$ for obtaining both radar and navigation data as well as for performing the hardware and program stacking (from 1 to 6192 times) of wave traces.

The average radio wave velocity (RWV) in firn and ice can calculate ice thickness from measured time delays of radar signals reflected from the bedrock. RWV depends on firn/ice density and temperature. We did not measure RWV $(V)$ at the western Elbrus plateau, but calculated the result as a function of glacier depth $(z)$ through measured ice-core density $\rho_{\mathrm{d}}(z)$ and borehole temperature $T(z)$ profiles:

$V(z)=c /\left[\varepsilon^{\prime}\left(\rho_{\mathrm{d}}, T\right)\right]^{1 / 2}$,

where $c=300 \mathrm{~m} \mathrm{ss}^{-1}$ - radio wave velocity in air; $\varepsilon^{\prime}\left(\rho_{\mathrm{d}}, T\right)$ is the dielectric permeability of snow, firn, and ice as a function of density $\rho_{\mathrm{d}}(z)$ and temperature $T(z)$ (Macheret, 2006).

$\varepsilon^{\prime}\left(\rho_{\mathrm{d}}\right)$ was calculated for two component dielectric mixture of ice and air (Looyenga, 1965):

$\varepsilon^{\prime}\left(\rho_{\mathrm{d}}, T\right)=\left\{\left(\rho_{\mathrm{d}} / \rho_{\mathrm{i}}\right)\left[\varepsilon_{\mathrm{i}}^{\prime}(T)^{1 / 3}-1\right]+1\right\}^{1 / 3}$,

where $\rho_{\mathrm{i}}=917 \mathrm{~kg} \mathrm{~m}^{-3}$ is the density of glacier ice.

$\varepsilon_{\mathrm{i}}^{\prime}(T)$ was calculated from Mätzler and Wegmüller (1987):

$\varepsilon_{\mathrm{i}}^{\prime}(T)=3.1884+0.0091 T$.

The average RWV of $180 \mathrm{~m} \mu \mathrm{s}^{-1}$ was calculated for the $181.8 \mathrm{~m}$ ice thickness at the drilling site, taking into account the depth variations from $\rho_{\mathrm{d}}$ and $T$ and the measured time delay of radio signal to ice thickness at each point.

We combined two data sets, from 2005 and 2007, to construct an ice thickness map. In total, we measured the glacier depth at more than 10000 sounding points along $6.5 \mathrm{~km}$ profiles, with an estimated accuracy of ice thickness measurements of $3 \%$ (Lavrentiev et al., 2010). The maximum depth was $255 \pm 8 \mathrm{~m}$ at the central part of the plateau, with minimum values of about $60 \mathrm{~m}$ near the edge. Radar records and digital elevation model ASTER GDEM averaged for 20002009 map the bedrock topography (Fig. 4). ASTER GDEM with an error of $\pm 20 \mathrm{~m}$ (ASTER GDEM Validation Team, 2009) is in a good agreement with the 1959 northern Caucasus topographic map and the 1997 digital orthophotomap of Elbrus (Zolotarev and Khar'kovets, 2000).

\subsection{Ice-core drilling and analysis}

\subsubsection{Methods}

Due to the promising glacier archive conditions obtained from the shallow ice coring in 2004 (see Sect. 2.2), a fulldepth ice-core drilling was completed on the western plateau from 27 August to 6 September 2009 (Mikhalenko, 2010). Bedrock was reached at the depth of $181.80 \mathrm{~m}$. Drilling was done in a dry borehole using the lightweight electromechanical drilling system developed by Geotech Co. Ltd., Nagoya, Japan. Technical details of the drill are described in Takeuchi et al. (2004). The recovered ice cores were subjected to stratigraphic observations, packed into plastic sleeves, and stored in a snow pit with temperatures of $-10^{\circ} \mathrm{C}$. Ice-core drilling was accompanied by borehole temperature measurements (using thermistor chains which were left for 3 days in the borehole and calibrated before and after the study with an error of $\pm 0.1^{\circ} \mathrm{C}$ ), and snow pit sampling conducted $30 \mathrm{~m}$ to the south of the drilling site. The ice core was shipped in a frozen condition to the cold laboratory of the Lomonosov Moscow State University where detailed stratigraphic descriptions, including photographing each piece of the core, and bulk density measurements, were conducted.

In addition to the 2009 deep ice core, a subsequent $12 \mathrm{~m}$ ice core was extracted in June 2012 at the same site to expand the existing ice-core sample set from 2009 to 2012. The 2012 ice core was also used for the dust study of Kutuzov et al. (2013). Finally, in 27-30 June 2013, a $20.36 \mathrm{~m}$ ice core was recovered at the same location.

Stratigraphic descriptions of the ice core were carried out using transmitted-light illumination, resulting in $1 \mathrm{~mm}$ resolution details of the depths and thickness of individual horizons. The density of firn and ice were measured on 457 individual samples. Figure 5 shows the bulk density distribution with depth. The sharp random outliers from the general profile, especially with the lower values, could result from uncertainties in estimations of samples lengths. The uncertainty increases for the denser and smaller samples.

Ionic species such as ammonium $\left(\mathrm{NH}_{4}^{+}\right)$succinate $\left(\mathrm{HOOCCH}_{2} \mathrm{COO}^{-}\right.$, also denoted succinic acid) were investigated along the uppermost $157 \mathrm{~m}$ of the Elbrus core (122 mw.e.) with the aim of aiding in the sampling of ice core for alpine firn and ice (Legrand et al., 2007a). Pieces of firn and ice were decontaminated in a clean air bench located in a cold room using a pre-cleaned electric plane tool. A total of 3350 subsamples were obtained along the $157 \mathrm{~m}$ borehole, 


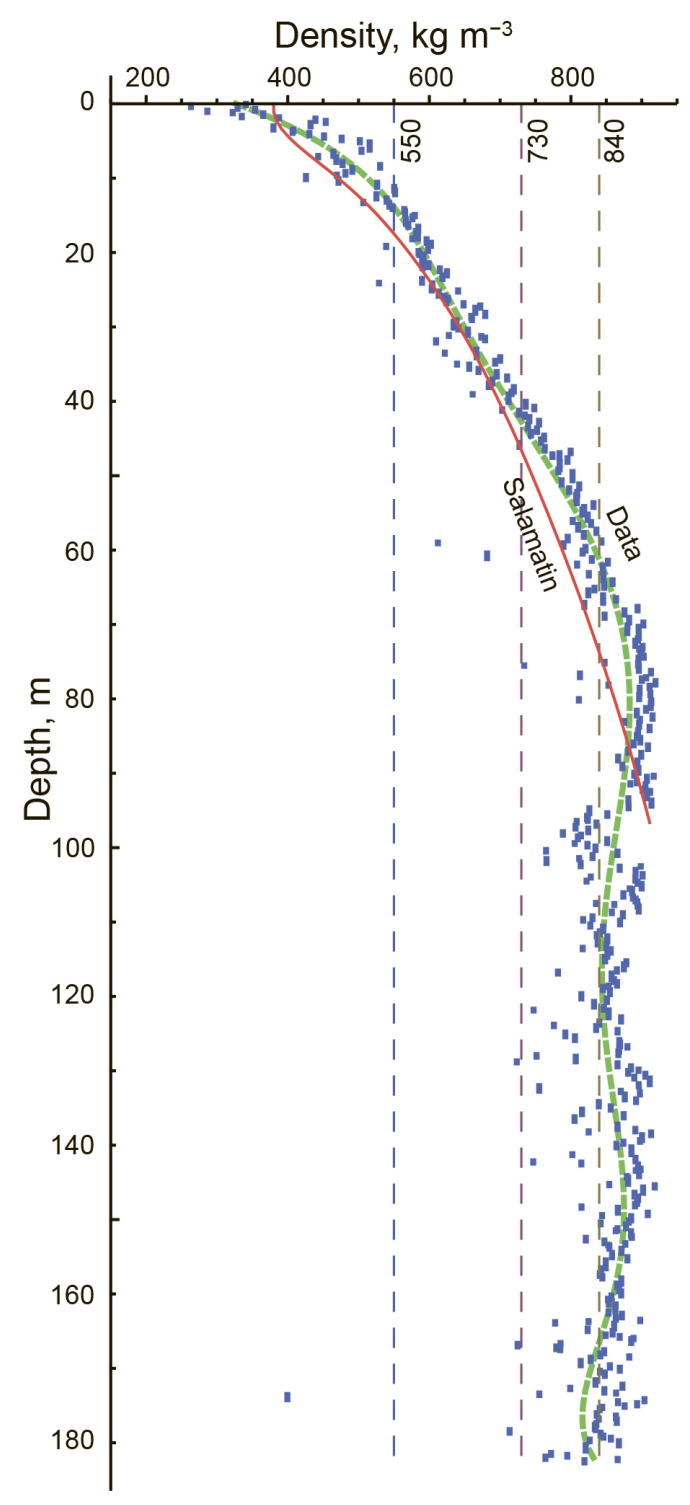

Figure 5. Measured (blue dots) and simulated (red line) ice-core density profile with critical densities shown as dashed lines (see Sect. 3.3.2). The green dashed line is a running mean for the measured density values.

with a sample resolution decreasing from $10 \mathrm{~cm}$ at the top to $2 \mathrm{~cm}$ at $157 \mathrm{~m}$ depth.

For cations $\left(\mathrm{Na}^{+}, \mathrm{K}^{+}, \mathrm{Mg}^{2+}, \mathrm{Ca}^{2+}\right.$, and $\left.\mathrm{NH}_{4}^{+}\right)$, a Dionex ICS-1000 chromatograph equipped with a CS12 separator column was employed. For anions, a Dionex 600 equipped with an AS11 separator column was used with an eluent mixture of $\mathrm{H}_{2} \mathrm{O}, \mathrm{NaOH}$ at $2.5,100 \mathrm{mM}$, and $\mathrm{CH}_{3} \mathrm{OH}$. A gradient pump system allows determining inorganic species $\left(\mathrm{F}^{-}, \mathrm{Cl}^{-}\right.$, $\mathrm{NO}_{3}^{-}$, and $\mathrm{SO}_{4}^{2-}$ ) as well as short-chain monocarboxylates (denoted $\mathrm{MonoAc}^{-}$) and dicarboxylates (denoted $\mathrm{DiAc}^{2-}$ ). For all investigated species, ion chromatography and ice-core decontamination blanks were found to be insignificant with respect to respective levels found in the ice-core samples.

As will be discussed in greater detail in Sect. 3.3.5, the search for volcanic horizons in the Elbrus ice cores requires examining the acidity (or alkalinity) of samples by evaluating the ionic balance between anions and cations where concentrations are expressed in micro-equivalents per liter, $\left.\mu \mathrm{Eq}^{-1}\right)$ :

$$
\begin{aligned}
& {\left[\mathrm{H}^{+}\right]=} \\
& \left(\left[\mathrm{F}^{-}\right]+\left[\mathrm{Cl}^{-}\right]+\left[\mathrm{NO}_{3}^{-}\right]+\left[\mathrm{SO}_{4}^{2-}\right]+\left[\mathrm{MonoAc}^{-}\right]+\left[\mathrm{DiAc}^{2-}\right]\right) \\
& -\left(\left[\mathrm{Na}^{+}\right]+\left[\mathrm{K}^{+}\right]+\left[\mathrm{Mg}^{2+}\right]+\left[\mathrm{Ca}^{2+}\right]+\left[\mathrm{NH}_{4}^{+}\right]\right) .
\end{aligned}
$$

Within the present study, we focus (Sect. 3.3.4) on the $\mathrm{NH}_{4}^{+}$and succinic acid profiles, in order to (1) define a criterion which allows the separation of winter and summer snow deposition and (2) to apply this criterion to the first $157 \mathrm{~m}$ of the Elbrus ice core, in order to establish a depth-age relationship based on both annual layer counting and the $\mathrm{NH}_{4}^{+}$and succinic acid depth profiles.

The shallow 2012 and 2013 ice cores and the deep (down to $106.7 \mathrm{~m}) 2009$ ice core were analyzed for deuteriumhydrogen $(\mathrm{D} / \mathrm{H})$ and oxygen $\left({ }^{18} \mathrm{O} /{ }^{16} \mathrm{O}\right)$ isotope ratios using a Picarro L1102-i instrument in the Climate and Environmental Research Laboratory (CERL), Arctic and Antarctic Research Institute, St. Petersburg, Russia. The instrument was calibrated on a regular basis with the isotopic standards V-SMOW, GISP, and SLAP provided by the International Atomic Energy Agency (IAEA) to estimate the precision of the measurements and to minimize the memory effect associated with continuous measurements. The reproducibility of the measurements was $\pm 0.07 \%$ ofor oxygen isotopes $\left(\delta^{18} \mathrm{O}\right)$ and $\pm 0.3 \%$ or deuterium $(\delta \mathrm{D})$. The CERL laboratory work standard SPB was measured after every five samples. The $\delta^{18} \mathrm{O}$ and $\delta \mathrm{D}$ values are expressed in \%o units relative to the V-SMOW value.

\subsubsection{Borehole temperatures}

Figure 6 shows the vertical temperature profile measured along the $181 \mathrm{~m}$ long borehole drilled in 2009. Temperatures ranged from $-17^{\circ} \mathrm{C}$ at $10 \mathrm{~m}$ depth to $-2.4^{\circ} \mathrm{C}$ at $181.8 \mathrm{~m}$. The temperature profile can be divided into three parts based on different temperature gradients: from the surface down to $10 \mathrm{~m}$, from 10 to $100 \mathrm{~m}$, and from $100 \mathrm{~m}$ to the glacier bottom. The upper section of the temperature profile reflects seasonal changes at the surface. The borehole temperature ranges from -17 to $-12^{\circ} \mathrm{C}$ between 10 and $100 \mathrm{~m}$, and most accurately reflects past temperature fluctuations. Temperature changes are almost rectilinear from $100 \mathrm{~m}$ depth to the glacier bottom and provide evidence of a steady heat transfer regime. The heat flux of $0.34 \mathrm{~W} \mathrm{~m}^{-2}$ at the glacier bottom was calculated from the measured temperature gradient and the coefficient of the heat conductivity of ice $\left(2.25 \mathrm{~W} \mathrm{~m}^{-2}\right)$. 


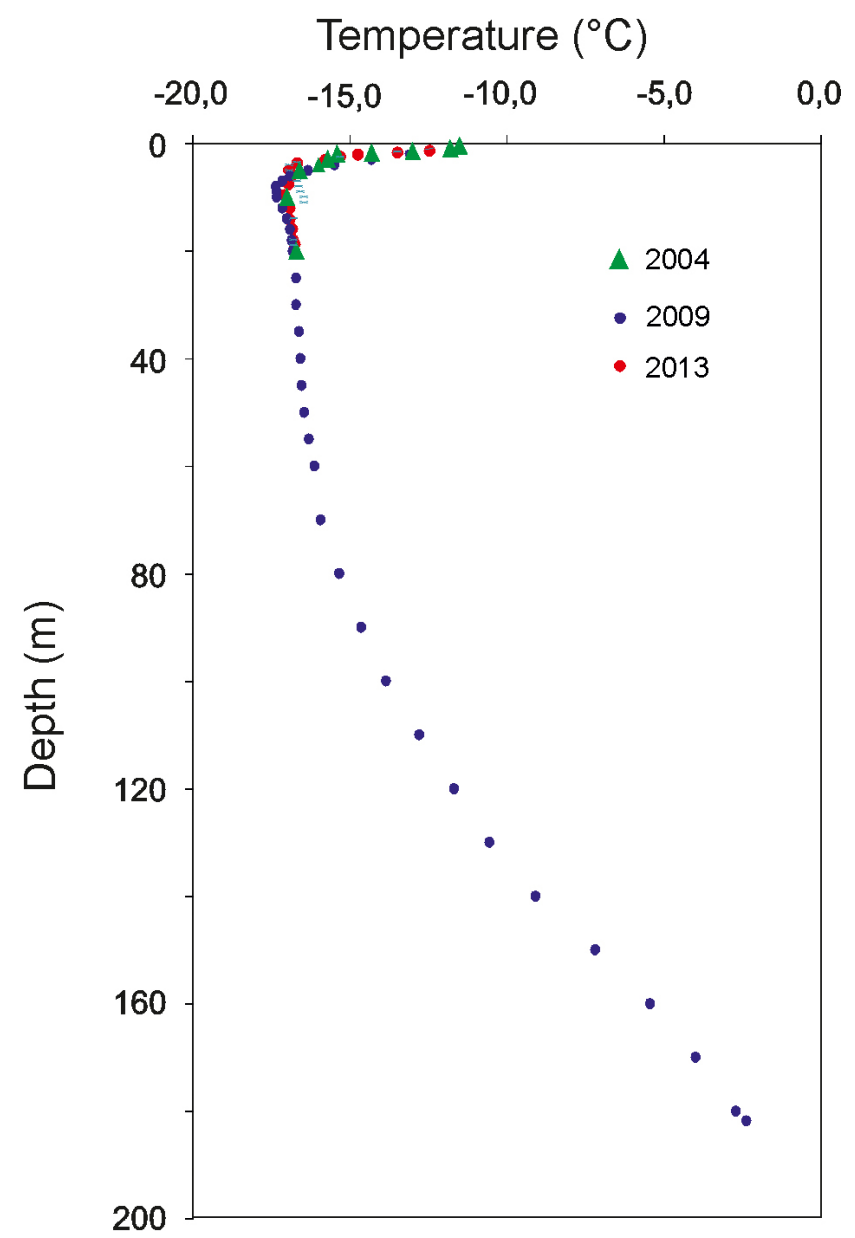

Figure 6. Measured temperature profiles at the western Elbrus plateau drill site for different dates: green triangles show the $22 \mathrm{~m}$ depth borehole drilled in 2004, blue dots show the main 2009 borehole, and red dots show the $20 \mathrm{~m}$ depth borehole drilled in 2013.

This value is $4-5$ times higher than the average heat flux density for the Earth's surface and higher than the mean value for central Caucasus, and may be associated with a heat magma chamber of the Elbrus volcano. Figure 6 also shows the temperature profile measured in the $19 \mathrm{~m}$ borehole in 2013 and temperature records obtained in 2004 after the $22 \mathrm{~m}$ depth shallow ice-core drilling on the western plateau (Mikhalenko et al., 2005). The good match between records is indicative of the stable temperature regime on the western Elbrus plateau for the last decade.

Using the altitudinal temperature gradient estimated in Sect. 3.1 based on western plateau AWS temperature data close to the 2009 drill site and the low-elevation station Mineralnye Vody, we estimate that the annual mean air temperature at the drill site is approximately $-19^{\circ} \mathrm{C}$. This value is close to the mean annual air temperature of $-19.4^{\circ} \mathrm{C}$, calculated using the general relationship with the ice temperature at the bottom of the active layer (Zagorodnov et al., 2006) and only slightly enhanced compared to the $10 \mathrm{~m}$ firn temperatures.

The measured temperature profile shows that basal melting can occur due to ice pressure at the deepest part of the glacier. Potential bottom melting has been estimated using a mathematical model of temperature regimes (Salamatin et al., 2001). Our modeling results demonstrate that basal melting occurs under ice thicknesses of more than $220 \mathrm{~m}$, but that its value does not exceed $10 \mathrm{~mm}$ w.e. $\mathrm{a}^{-1}$.

\subsubsection{Bulk density and ice-core stratigraphy}

The bulk density profile suggests a change in densification around the critical densities (Maeno and Ebinuma, 1983) of 550 and $840 \mathrm{~kg} \mathrm{~m}^{-3}$, and no visible change at $730 \mathrm{~kg} \mathrm{~m}^{-3}$, which is consistent with other analyses of density profiles (Hörhold et al., 2011; Ligtenberg et al., 2011). However, the slight decreasing trend in density at depths below the maximum values at $\sim 80 \mathrm{~m}$ (Fig. 5), close to the critical density across the whole depth interval, is unlikely to be a systematic error in measurements and needs further investigation. $\mathrm{Fu}-$ ture research should account for the ice flow characterization and the possible effects related to the "intervening depth interval" (the alternation of layers which have already reached the close-off density, with layers that are still permeable) due to seasonal (Bender et al., 1997) or wind-induced (due to seasonal differences in wind speeds) snow density variability at high accumulation sites. Unlike polar ice cores where the "intervening depth interval" is just a fraction of the whole length of the ice core (Bender et al., 1997), the measured bulk density in the Elbrus ice core spans a wide interval between 800 and $915 \mathrm{~kg} \mathrm{~m}^{-3}$ towards the bottom of the glacier (Fig. 5). Comparing Elbrus's density profile with the results from the Salamatin et al. (2009) densification model demonstrates that there is an increase in the accumulation rate over the past several years. The minimum deviation between simulated and measured ice-core density profiles occurred when the accumulation history was assumed to be similar to the long-term precipitation changes observed at meteorological stations (Nosenko et al., 2013).

According to the morphogenetic classification of stratigraphic features (Arkhipov et al., 2001), two distinct types of layering were observed in the core: firn layers which have not been affected by melting, and ice layers formed by the refreezing of meltwater in the surface snow. The thickness of the infiltration ice layers, which do not form every year, does not exceed $10 \mathrm{~mm}$. Ice formation occurs in cold, dry conditions, as already concluded on the basis of borehole and air temperatures at the drill site (see Sects. 3.1, 3.3.2). The pore close-off depth occurs at around $55 \mathrm{~m}$, where the air bubbles separate from the surrounding ice matrix. This depth coincides with a measured bulk density of around $840 \mathrm{~kg} \mathrm{~m}^{-3}$. This density is consistent with the presence of ice layers, as these layers increase the close-off density value above what is expected in ice in which no melting occurs (i.e., $830 \mathrm{~kg} \mathrm{~m}^{-3}$ ). 


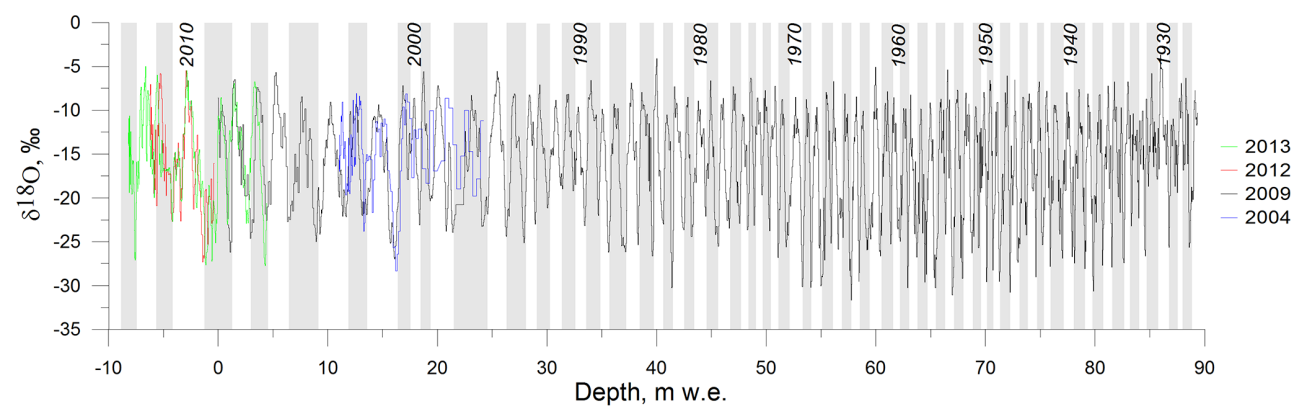

Figure 7. $\delta^{18} \mathrm{O}$ profiles of the cores obtained in 2004, 2009, 2012, 2013. $0 \mathrm{~m}$ depth corresponds to the 2009 surface. Grey and white boxes depict annual layers.

\subsubsection{Seasonal ice-core stratigraphy of stable water isotopes}

The seasonal cycle of the isotopic composition is detectable over the entire measured part of the core (Fig. 7). Mean seasonal values of $\delta \mathrm{D}$ are $-200 \%$ for the winter and $-25 \%$ o for the summer. Values of $\delta^{18} \mathrm{O}$ are about -5 to $-10 \%$ o in summer and $-30 \%$ in winter. Using isotope values to determine annual cycles over $106.7 \mathrm{~m}$ of the ice core suggests that this $106.7 \mathrm{~m}$ covers 86 years (AD 1924-2009). The mean accumulation rate for this period, based on this dating and taking the firn density and layer thinning into account, was $1455 \mathrm{~mm}$ w.e. Figure 7 shows results of isotopic measurements of four different ice cores obtained from the western Elbrus plateau. While 2009, 2012, and 2013 cores were obtained from almost the same location; the 2004 core was drilled $120 \mathrm{~m}$ to the southwest. Good agreement in isotopic variations of all cores suggests a relatively homogeneous snow deposition on the plateau.

We used the isotope diffusion model of Johnsen et al. (2000) to estimate the preservation of the isotopic signal with diffusive smoothing. Although the drilling site is located in a relatively warm place $\left(-17^{\circ} \mathrm{C}\right)$, the high snow accumulation rate does not favor strong diffusion, since any firn layer rapidly reaches the pore close-off depth. The maximum "diffusion length" at the pore close-off depth is estimated as $5 \mathrm{~cm}$ in ice equivalent (IE). The effective diffusion length may be even smaller if we take into account the ice lenses in the firn that prevent the vertical exchange of the water molecules.

Such a diffusion length means that all oscillations shorter than $13 \mathrm{~cm}$ IE, will be completely erased due to the diffusion, while oscillations between 13 and $70 \mathrm{~cm}$ IE will survive but will be damped to some extent, and the cycles longer than $70 \mathrm{~cm}$ (e.g., the annual cycle) IE will not be affected by the diffusion. Thus, if during a single snowfall results in a $35 \mathrm{~cm}$ snow layer (that corresponds to $13 \mathrm{~cm} \mathrm{IE}$ ), the isotopic signal of this layer will survive during the diffusion processes and will be seen in the ice core.

Diffusion occurs below the pore close-off depth, but the in ice is much slower than in firn. The final diffusion length solely depends on the time and temperature of the firn-ice thickness. Even if we take a maximum possible temperature $\left(-2.4^{\circ} \mathrm{C}\right)$ and an age estimate of a few hundred years, the additional diffusion in ice will still be very small. This combination leads us to an important conclusion; we may expect to obtain seasonal cycles in the isotope profile down to the very bottom of the core, and our ability to detect the annual cycle in the core depend on the sampling resolution, as well as on such basal processes such as layer folding and mixing.

\subsubsection{Seasonal ice-core stratigraphy of chemical parameters and ice-core dating based on annual layer counting}

We attempted to date the core by counting annual layers based on chemical ice-core stratigraphical records, as we previously successfully applied such layer counting to midlatitude Alpine ice cores using the $\mathrm{NH}_{4}^{+}$signal (Preunkert et al., 2000). Since $\mathrm{NH}_{4}^{+}$experiences strong maximum emissions in phase with strengthened summer upward transport of air masses, a particularly well-pronounced seasonal cycle is expected, such as observed at the Col du Dôme Alpine site (Preunkert et al., 2000; Fagerli et al., 2007). However, it appears that the $\mathrm{NH}_{4}^{+}$seasonal cycle at Elbrus is less pronounced than in the Alps. Whereas recent summer $\mathrm{NH}_{4}^{+}$levels are comparable at both sites, recent winter concentrations at Elbrus are significantly higher than at Col du Dôme.

The first study regarding the seasonality of Elbrus snow accumulation was conducted by Kutuzov et al. (2013) along a short firn core spanning the years 2012-2009. Based on the dust layer stratigraphy of absolute-dated dust events and the stable isotope record the authors showed that the annual deposition at Elbrus has a mean $\delta^{18} \mathrm{O}$ signature of $-15 \%$. The isotopic signature consists of nearly equal deposition amounts from the warm season ( $45 \%$ of total accumulation), where $\delta^{18} \mathrm{O}$ values vary between -5.5 and $-10 \%$, and from the cold season ( $55 \%$ of total accumulation), for which values vary between -17 and $-27 \%$.

The concentration distribution of $\mathrm{NH}_{4}^{+}$values was inspected in recent firn layers ( $0-12 \mathrm{~m}$ w.e. $)$, and the $50 \%$ concentration limit of $100 \mathrm{ppb}$ was a first approach to separate 

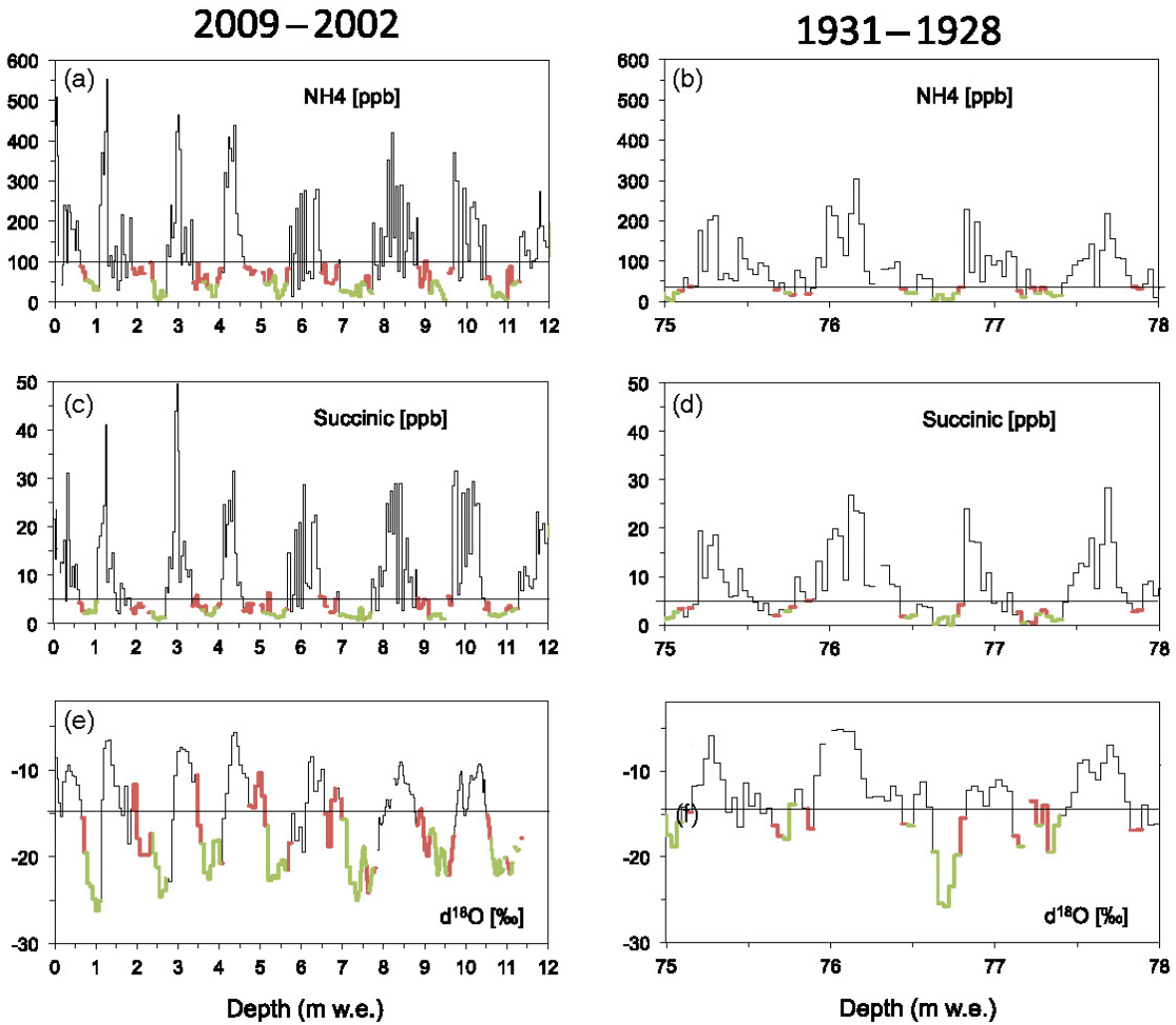

Figure 8. Seasonal variations in $\mathrm{NH}_{4}^{+}(\mathbf{a}, \mathbf{b})$, succinic acid $(\mathbf{c}, \mathbf{d})$, and $\delta^{18} \mathrm{O}(\mathbf{e}, \mathbf{f})$ for different sections of the Elbrus ice core. Red sections demonstrate winter samples based on the following criteria: succinic acid less than $5 \mathrm{ppb}, \mathrm{NH}_{4}^{+}$less than 100 ppb for recent years, and less than $50 \mathrm{ppb}$ prior to 1950 . Green sections meet the following winter-background criterion: succinic acid less than $3 \mathrm{ppb}, \mathrm{NH}_{4}^{+}$less than $50 \mathrm{ppb}$ for recent years, and less than $20 \mathrm{ppb}$ prior to 1950 . Black bars in ionic plots refer to the winter criteria. The black bars in the $\delta^{18} \mathrm{O}$ plots refer to the respective mean values.

snow deposition arriving from summer and winter precipitation at Elbrus. However this criterion is not conserved in time as the $\mathrm{NH}_{4}^{+}$sources are mainly anthropogenic in origin, with an expected $\mathrm{NH}_{4}^{+}$trend in summer as well as in winter over the last 100 years. Therefore, a second criterion was used to confirm our winter snow selection. This criterion used succinic acid, a light dicarboxylic acid with an observed strong summer maximum; and a winter level is almost non-existent in the current atmosphere in Europe (Legrand et al., 2007b). The very low winter levels are related to the absence of source as this species is mainly photochemically produced from biogenic precursors. The concentration distribution of succinate values was inspected in recent firn layers ( $0-12 \mathrm{mw}$.e.), and the $50 \%$ concentration limit of $5 \mathrm{ppb}$ separates snow deposition arriving from summer and winter precipitation at Elbrus. Winter snow and ice layers were identified when both ammonium and succinate criteria were fulfilled for more than two successive samples.

Figure 8a, shows the result of this data dissection over the uppermost $12 \mathrm{mw}$.e. along with the $\delta^{18} \mathrm{O}$ record (Fig. 8e). The mean $\delta^{18} \mathrm{O}$ level of selected winter data is $-19.6 \%$, and as demonstrated in Fig. 8a and c, the winter season selected from ammonium and succinate concentrations matches with winter sections deduced from the $\delta^{18} \mathrm{O}$ profile quite well. However, when examining the $\delta^{18} \mathrm{O}$ variability compared to the major ions, it appears that sometimes the spring season or even the beginning of the summer season may be included. For dating by annual layer counting, this shortcoming is not critical; however, if the data set is inspected at seasonal resolution this definition of the spring season might be a handicap. In this case a stronger criteria $\left(\mathrm{NH}_{4}^{+}<50 \mathrm{ppb}\right.$ and succinate $<3 \mathrm{ppb}$ ) may be applied in addition to ensure that only deposition corresponding to winter precipitation and associated atmospheric background conditions are selected within the winter period. The mean $\delta^{18} \mathrm{O}$ level of winter data selected using this criteria is $-21.1 \%$, whereas seen in Fig. 8a, $\mathrm{c}$, and e, this selection may omit some winter seasons.

Examination of $\mathrm{NH}_{4}^{+}$and succinate minima below a depth of $12 \mathrm{~m}$ contrasts with results from the European Alps, where in Elbrus the $\mathrm{NH}_{4}^{+}$winter level decreases significantly from near the surface to around $70 \mathrm{mw}$.e. depth (see Fig. 8). Therefore, the $\mathrm{NH}_{4}^{+}$winter and background criteria were adjusted using a winter (background) threshold of $50 \mathrm{ppb}$ $(30 \mathrm{ppb})$ from 52 to $62 \mathrm{~m}$ w.e. of the core and $30 \mathrm{ppb}(20 \mathrm{ppb})$ 


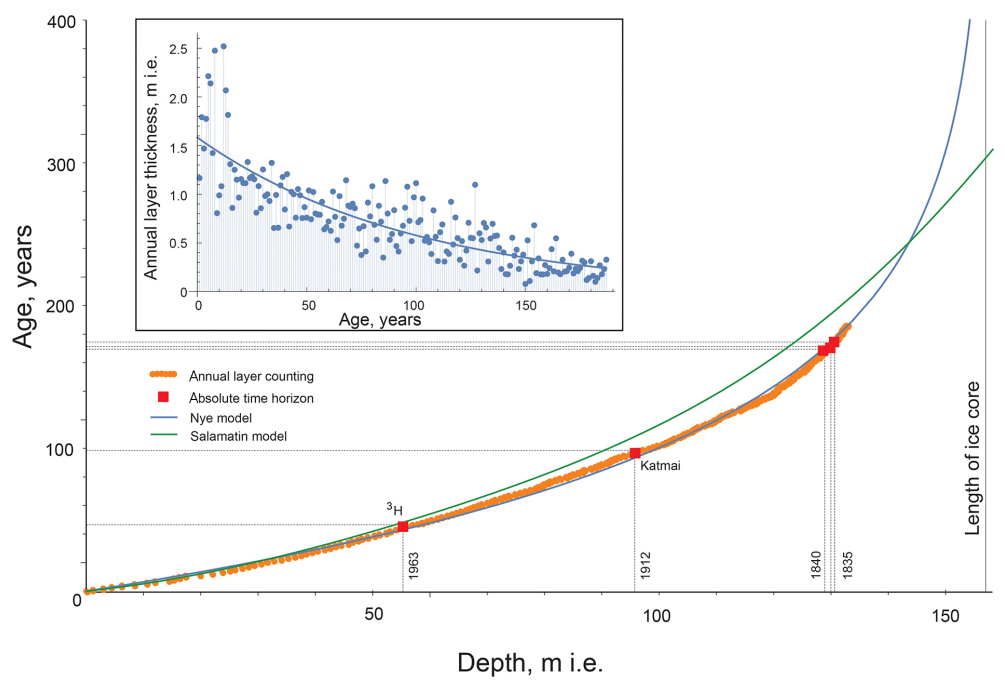

Figure 9. Depth (ice equivalent in $\mathrm{m}$ )/age relation established for the Elbrus ice core by annual layer counting along the depth profile using ionic species (orange dots), and applying the ice flow models: Nye (blue line) and Salamatin (green line). The insert represents the annual layer thickness (ice equivalent in $\mathrm{m}$ ) and the Nye least square fit (see text).

from below a core depth of $62 \mathrm{mw}$.e. In contrast, the succinate winter levels did not change and the 5 ppb criterion applied in recent times was also applied in deeper layers. Figure $8 \mathrm{~b}, \mathrm{~d}$, and $\mathrm{f}$ showed a comparison of $\mathrm{NH}_{4}^{+}$, succinate with the $\delta^{18} \mathrm{O}$ record between 75 and $78 \mathrm{~m}$ w.e. (i.e., from AD 1931 to 1928). The winter criteria match well with recent winter deposition as deduced from the stable isotope content, although the stable isotope record tends to already be a bit smoothed compared to the uppermost firn layers. As observed for the uppermost core section, we cannot exclude that the winter criteria include parts of an intermediate season, whereas the background criteria select only deposition arriving from the coldest precipitation.

Figure 9 shows the result of the dating of the Elbrus ice core. In addition to model calculations detailed in Sect. 3.4, the depth-age scale obtained by annual layer counting using the $\mathrm{NH}_{4}^{+}$and succinate criteria is reported down to $122 \mathrm{~m}$ w.e. Annual layer counting was achieved as described above down to $85 \mathrm{mw}$.e. Below $85 \mathrm{mw}$.e., winter levels became rather thin due to annual layer thinning but also likely due to upstream effects as commonly encountered on such small-scale glaciers (Preunkert et al., 2000). Therefore, below $85 \mathrm{~m}$ w.e. ice-core layers, in which fewer than three samples had reached the winter criteria were considered as winter seasons, and from 113 to $122 \mathrm{mw}$.e. winter layers were also assigned when only one of the two criteria was fulfilled for at least one sample, while the other sample showed only a relative minimum that sometimes exceeded the fixed threshold. This lack of sharp minima could be either due to the fact that winter sections become smaller than our sampling resolution of $2-3 \mathrm{~cm}$ applied to core depths below $90 \mathrm{mw}$.e., and/or could be the result of an incomplete precipitation preservation due to wind erosion upstream of the borehole as ob- served on other small-scale Alpine glacier sites (e.g., Preunkert et al., 2000). In this latter case a systematic lack of winter snow accumulation would occur in the deeper ice-core layers.

Dating based on annual layer counting of the chemical stratigraphy agrees fairly well with the AD 1963 tritium time horizon located at the core depth of $50.7 \mathrm{mw}$.e. and which is dated at AD 1965 using the ammonium stratigraphy; Fig. 10a. The layer counting results fit well with the dating achieved to $106.7 \mathrm{~m}$ based on the seasonal stratigraphy of the stable isotope profile. Whereas stable isotopes predict the year AD 1924 at a core depth of $106.7 \mathrm{~m}$, the chemical stratigraphy leads to an estimate of the year AD 1926 at this depth.

To anchor the depth-age relationship with further absolute time horizons, we inspected the sulfate profile to identify volcanic horizons such as found in other northern hemispheric ice cores between AD 1912 (Katmai) and AD 1783 (Laki) in Greenland (Legrand et al., 1997; Clausen et al., 1997) and at Colle Gnifetti (Bohleber 2008). However, since Elbrus is a volcanic crater, it is sometimes difficult to attribute a peak either to a well-known global eruption or to a local event. Furthermore, numerous sulfate peaks in the Elbrus ice core originate from terrestrial input as suggested by the presence of concomitant calcium peaks. The Katmai eruption in AD 1912 could be clearly identified at $87.7 \mathrm{mw}$ we. (dated at AD 1911 using the ammonium stratigraphy), with several neighboring samples showing relatively high sulfate levels (up to $1200 \mathrm{ppb}$, i.e., $25 \mu \mathrm{EqL}^{-1}$ ) compared to sulfate peaks generally present in summer layers in the early 20th century. Furthermore, in contrast to neighboring summer sulfate peaks located at $87.2,87.4,88.0$, and $89.3 \mathrm{~m}$ w.e. that are alkaline (see Fig. 10b), the acidity of samples of 

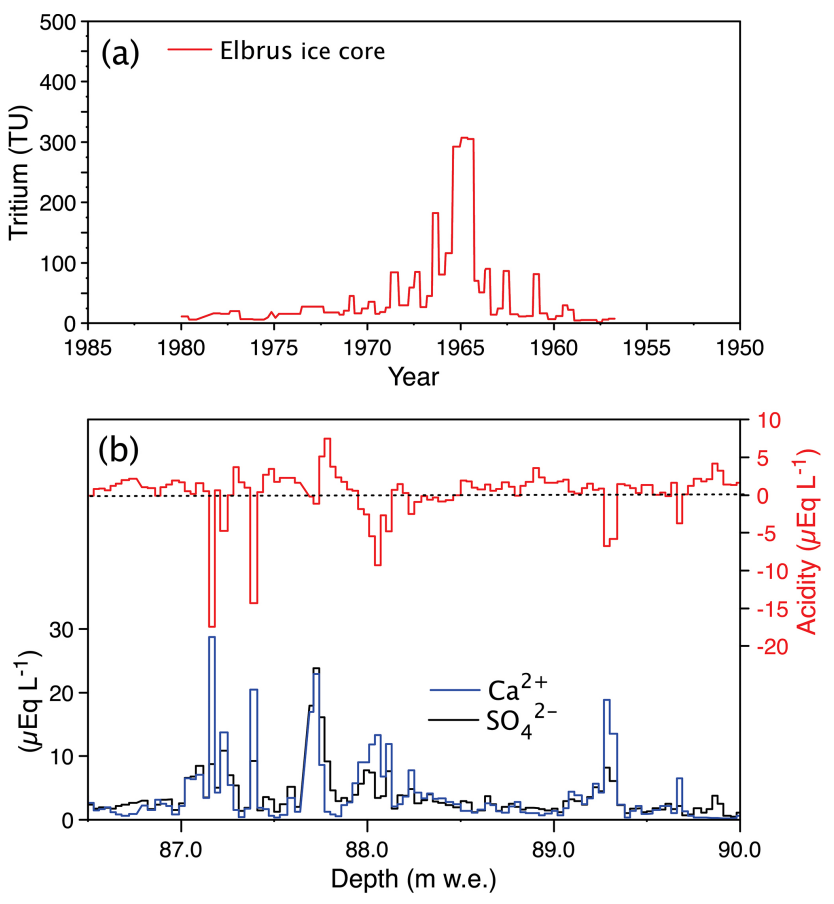

Figure 10. Absolute time horizons: (a) tritium measurements made on Elbrus ice-core samples (data were converted to 2009 with regard to the half-life time of tritium, $T_{1 / 2}=12.32$ year). The dates reported in the tritium curve are derived from the ammonium stratigraphy. (b) Calculated acidity (top; see Sect. 3.3.1), and calcium and sulfate (bottom) in ice layers located between 86.5 and 90 mw.e.

the $87.7 \mathrm{~m}$ w.e. sulfate peak reaches $8 \mu \mathrm{EqL} \mathrm{L}^{-1}$. Furthermore, samples located at the top part of the $87.7 \mathrm{~m}$ w.e. sulfate peak remain neutral in spite of a large presence of calcium. Figure 11 demonstrates that the 1-year uncertainty in dating this horizon is in excellent agreement with our annual counting.

We were still able to easily examine annual counting down to $113 \mathrm{~m}$ w.e. resulting in a date of $\mathrm{AD} 1860$, but below this depth the dating becomes more uncertain (see the green line in Fig. 9). Below $88 \mathrm{~m}$ w.e., seven significant potential volcano horizons are suspected based on their ionic balance and sulfate levels (not shown), from which at least one horizon is of local origin as suggested by small stones up to 1$2 \mathrm{~mm}$ in the corresponding ice layer. Nevertheless, a series of three narrow ionic spikes occur at 118-120 m w.e. (dated at $\sim$ AD 1840-1833), where two of the spikes are characterized by an increase of sulfate and acidity (up to $7.8 \mu \mathrm{EqL}^{-1}$, not shown) that may be related to the well-known eruptions observed in Greenland that are dated to AD $1840 \pm 2$ years. One of these eruptions may possibly be due to the Coseguina eruption in AD 1835 (Legrand et al., 1997).

We calculated the depth-age relationship from the depths and thicknesses of the counted annual layers (Fig. 9). Despite high variability in the annual layers' thickness, the data demonstrate layer thinning with depth related to the ice flow.

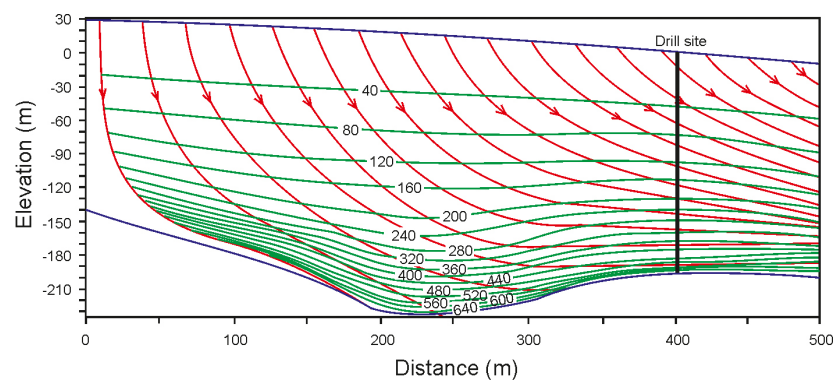

Figure 11. Vertical transect of the western Elbrus plateau glacier along a reference flow line. Predicted ice-particle paths (lines with arrows) and isochrones are shown.

Applying the thickness-age relationship developed by Nye (Dansgaard and Johnsen, 1969) to the actual annual layer data (Fig. 9) provides the mean accumulation over the whole studied time period in the ice core resulting in $1.583 \mathrm{~m}$ of ice equivalent per year. The Nye curve corresponds to the depthage relationship from Nye's model with a best-fit (constant over time) accumulation rate and the glacier thickness at the drilling site (Fig. 9). The green line is the depth-age relationship as suggested by Salamatin's model (Salamatin et al., 2000) with the same best-fit accumulation rate and drill site basal and surface descriptions as assumed when applying Nye's model.

Dating based on annual layer counting of the chemical stratigraphy agrees well with the AD 1963 time horizon that is located at the core depth of $50.7 \mathrm{~m}$ w.e. (dated at 1965 using the ammonium stratigraphy, Fig. 10a). In addition it fits very well with the dating achieved so far (i.e., core down to $106.7 \mathrm{~m}$ ) on the base of the seasonal stratigraphy of the stable isotope profile. Whereas stable isotopes predict the year 1924 at a core depth of $106.7 \mathrm{~m}$, the chemical stratigraphy leads to an estimation of the year 1926 in this depth.

To anchor the depth age relation with further absolute time horizons, a first inspection of the sulfate profile was made with the view to identify volcanic horizons as found in other northern hemispheric ice cores between 1912 (Katmai) and 1783 (Laki eruption) in Greenland (Legrand et al., 1997; Clausen et al., 1997) and at Colle Gnifetti (Bohleber, 2008). However since the Elbrus is an in active volcanic crater, it is sometimes difficult to attribute a peak either to a wellknown global eruption or to a local event. Furthermore, numerous sulfate peaks in the Elbrus ice core originate from terrestrial inputs as suggested by the presence of concomitant calcium peaks. So far, the Katmai eruption in 1912 could be clearly identified at $87.7 \mathrm{mw}$.e. (dated at 1911 using the ammonium stratigraphy) with several neighboring samples showing relatively high sulfate levels (up to $1200 \mathrm{ppb}$, i.e., $25 \mu \mathrm{EqL}^{-1}$ ) compared to those seen in sulfate peaks generally present in summer layers of the early 20th century. Furthermore, as seen in Fig. 10b, in contrast to neighboring summer sulfate peaks located at $87.2,87.4,88.0$, and $89.3 \mathrm{~m}$ w.e., 
that are alkaline (see Fig. 10b), the acidity of samples of the $87.7 \mathrm{~m}$ w.e. sulfate peak reaches $8 \mu \mathrm{EqL}^{-1}$ at the bottom part of the sulfate peak. Furthermore, samples located at the top part of the $87.7 \mathrm{~m}$ w.e. sulfate peak remain neutral in spite of a large presence of calcium (similar to those seen in neighboring summer sulfate peaks). As seen in Fig. 9 it appears that within 1-year uncertainty, this horizon is in excellent agreement with our annual counting.

Below $88 \mathrm{mw}$.e., we were still able to easily proceed annual counting down to 113 (1860); whereas further down, the dating become more uncertain (see the green line in Fig. 9). Below $88 \mathrm{~m}$ w.e., seven significant potential volcano horizons can be suspected on the basis of the ionic balance and sulfate levels (not shown), from which however at least one are of local origin (as suggested by small stones with size of up to $1-2 \mathrm{~mm}$ were found in the corresponding layer). Nevertheless, a series of three narrow spikes was located at 118$120 \mathrm{~m}$ w.e. (dated at around 1840-1833) among which two that are characterized by an increase of sulfate and acidity (up to $7.8 \mu \mathrm{EqL}^{-1}$, not shown) may be related to the wellknown eruptions observed in Greenland in a time distance of 2 years around 1840 (one of them being possibly due to the Coseguina eruption in 1835) (Legrand et al., 1997).

\subsection{Modeled ice flow and ice-core dating}

Mountain glaciers in present volcanic craters have different thermodynamic properties than other mountain glaciers. The limited ice flux over the crater rims forms flat glacier surfaces with low surface ice velocity. The intense volcanic heat flux may result in basal melting and the associated removal of the oldest basal layers. A simplified thermomechanically coupled model for simulating ice flow along a fixed flow tube and heat transfer in ice caps filling volcanic craters was developed by Salamatin et al. (2000). The model description and ice-flow and heat-transfer equations are described in detail in Salamatin et al. (2000). The model takes into account surface and bedrock topography and snow-firn densification parameters (see Sect. 3.3.2), the distribution of the basal melt rate (see Sect. 3.3.1), and normalizes the results by the present-day accumulation rate. We calculated the depthage relationship for the western Elbrus plateau using the recent accumulation rate of $1200 \mathrm{~mm}$ w.e. The ice melt rate at the glacier bedrock is negligible and comprises less than $10 \mathrm{mmw}^{-\mathrm{a}^{-1}}$ (see Sect. 3.3.1) in the deepest glacier sections. Figure 11 shows the cross section of the western Elbrus plateau along a reference flow line. Predicted ice flow paths are shown by lines with arrows while isochrones are designated by numbers which specify the ice age in years.

\section{Conclusions}

Paleoclimatological records for southern and eastern Europe are based on geomorphological, palynological, limnologi$\mathrm{cal}$, and dendrochronological data. Ice-core records have not been taken into account as a source of paleoclimatological and environmental information for this area due to rapid glacier mass exchange rate and significant surface melt, often resulting in smoother isotopic and chemical profiles in glacier records. However, the deep Elbrus ice core drilled in 2009 at $5115 \mathrm{~m}$ a.s.l. provides new evidence for significant regional-scale multiproxy climatic implications. The negative ice temperature of the glacier at the drilling site results in an undisturbed incoming climate signal. The considerable snow accumulation rate of $1455 \mathrm{~mm}$ w.e. coupled with highresolution ice-core sampling allows us to separate snow seasonal climate signals from summer and winter precipitation. Annual layers were differentiated on the basis of seasonal oscillations of $\mathrm{NH}_{4}^{+}$, succinic acid, and $\delta^{18} \mathrm{O}$. Annual layer counting was confirmed by the well-known reference horizons of the AD 1963 nuclear tests and the AD 1912 Katmai volcanic eruption. Annual layer counting extends down to 85 mw.e. Ice flow models show that the basal ice age at the maximum glacier depth of $255 \mathrm{~m}$ is more than 600 years BP. The 2009 drilling site was situated downstream from this maximum depth location and the resulting basal ice age does not exceed 350-400 years BP. An essential difference between reported depth-age scale constructed from annual layer counting versus the age scale created from flow models requires the inspection of the model algorithm and the development of a reliable ice flow model.

The combination of the different glacio-chemical features of the western Elbrus plateau detailed in this study demonstrates that this high elevation glacier archive offers the possibility to extract relevant atmospheric information from longterm ice-core records in the Caucasus. Ongoing research is therefore dedicated to reconstructing several key aspects of the changing atmosphere of this central European region, in particular for various aerosol components such as sulfate, ammonium, terrigenous matter, and carbonaceous compounds or fractions and species related to the nitrogen cycle. The comparison of Elbrus ice core with ice-core records from Alpine glaciers (Col du Dôme and Colle Gnifetti) will allow us to estimate the tendency of climatic changes over Europe for the last few centuries, and to obtain high-resolution multiproxy reconstructions of atmospheric chemistry, air temperature and precipitation oscillations, black carbon pollution, and atmospheric circulation change.

Acknowledgements. The ice-core recovery in 2009 was funded by the Russian Foundation for Basic Research (RFBR) grants 07-05-00410 and 09-05-10043. V. Mikhalenko, S. Kutuzov, and I. Lavrentiev acknowledge support of the Russian Academy of Sciences (Department of Earth Sciences ONZ-12 Project) and RFBR grant 14-05-00137. S. Sokratov acknowledges support of 
the RSF (project 14-37-00038) in his contribution to the paper. The ongoing laboratory analyses at LGGE and logistics were supported by the EU FP7 IP PEGASOS (FP7-ENV-2010/265148), the French ANR program PAPRIKA (ANR-09-CEP-005-02), the CNRS-DFG bilateral project entitled "Secondary organic aerosol production in the lower free troposphere over western Europe", and the LEFECHAT program ESCCARGO. Stable water isotopic analyses were supported by the RFBR grant 14-05-31102 (A. Kozachek, A. Ekaykin, and V. Lipenkov, AARI) and IAEA research contracts 16184/R0 (Stable water isotopes in the cryosphere of the Northern Eurasia), and 16795 (Paleo-Climate Isotope Record from European Mt. Elbrus Ice Core). This research work was conducted in the framework of the International Associated Laboratory (LIA) "Climate and Environments from Ice Archives" 2012-2016, linking several Russian and French laboratories and institutes. Two anonymous reviewers and the editor are acknowledged for their valuable comments and suggestions to improve the manuscript. The authors thank Natalie Kehrwald for her help in tuning the language.

Edited by: O. Eisen

\section{References}

Abich, H.: Geologische Beobachtungen auf Reisen im Kaukasus im Jahre 1873, Bulletin de la Société impériale des naturalistes de Moscou, 48(2), 278-342 + 1 Karte, 1874.

AMAP: Snow, Water, Ice and Permafrost in the Arctic (SWIPA): Climate Change and the Cryosphere, Arctic Monitoring and Assessment Programme (AMAP), Oslo, 538 pp., 2011.

Anisimov, O. A. and Zhil'tsova, E. L.: Climate change estimates for the regions of Russia in the 20th century and in the beginning of the 21 st century based on the observational data, Russ. Meteorol. Hydrol., 37, 421-429, doi:10.3103/S1068373912060106, 2012.

Arkhipov, S. M., Mikhalenko, V. N., Thompson, L. G., Zagorodnov, V. S., Kunakhovich, M. G., Smirnov, K. E., Makarov, A. V., and Kuznetsov, M. P.: Stratigrafiya deyatelnogo sloya lednikovogo kupola Vetreniy na ostrove Graham Bell, Zemlya Frantsa Iosifa (Stratigraphy of the active layer of the Vetreny Ice Cap, Graham Bell Island, Franz Josef Land), Materialy glyatsiologicheskikh issledovanii (Data Glaciol. Stud.), 90, 169-186, 2001 (in Russian with English summary).

ASTER GDEM Validation Team: ASTER Global DEM Validation Summary Report, Sioux Falls, USA, 28 pp., 2009.

Baranov, S. and Pokrovskaya, T.: Rabota meteorologicheskoi gruppy EKNE 1935 (Meteorological observations made on the Elbrus by the complex expedition of the Academy of Sciences of the USSR in 1935), in: Trudy Elbrusskoy ekspeditsii Akademii nauk SSSR 1934 i 1935 (Elbrus expedition of the Academy of Sciences and of the Institute of Experimental Medicine of the USSR, 1934 and 1935), edited by: Vavilov, S. I., Academy of Sciences Press, Moscow, Leningrad, 199-209, 1936 (in Russian with English summary).

Barbante, C., Schwikowski, M., Ring, T., Gäggeler, H. W., Schotterer, U., Tobler, L., Van de Velde, K., Ferrari, C., Cozzi, G., Turetta, A., Rosman, K., Bolshov, M., Capodaglio, G., Cescon, P., and Bourton, C.: Historical record of European emissions of heavy metals to the atmosphere since the 1650 s from Alpine snow/ice cores drilled near Monte Rosa, Environ. Sci. Technol., 38, 4085-4090, doi:10.1021/es049759r, 2004.

Bazhev, A. B. and Bazheva, V. Y.: Stroenie firnovo-ledyanoy tolschi na Elbruse (Structure and firn-ice layer at the south slope of Elbrus), Materialy glyatsiologicheskikh issledovanii (Data Glaciol. Stud.), 10, 94-100, 1964 (in Russian with English summary).

Bazhev, A. B., Rototaeva, O., Heitzenberg, J., Stenberg, M., and Pinglot, J. F.: Physical and chemical studies in the region of the southern slope of Mount Elbrus, Caucasus, J. Glaciol., 44, 214222, 1998.

Bender, M., Sowers, T., and Brook, E.: Gases in ice cores, P. Natl. Acad. Sci. USA, 94, 8343-8349, doi:10.1073/pnas.94.16.8343, 1997.

Berikashvili, V. S., Vasilenko, E. V., Macheret, Y. Y., and Sokolov, V. G.: Odnoimpulsniy radar dlya zondirovaniya lednikov s opticheskim kanalom sinkhronizatsii (Monopulse radar for glacier sounding with optical channel for synchronization and digital signal processing), Radiotechnica (Radio technics), 9, 52-57, 2006 (in Russian with English summary).

Bohleber, P.: Age Distribution and $\delta{ }^{18} \mathrm{O}$ Variability in a Low Accumulation Alpine Ice Core: Perspective For Paleoclimate Studies, Diploma thesis, Fakultät für Physik und Astronomie, RuprechtKarls-Universität, Heidelberg, 147 pp., 2008.

Clausen, H. B., Hammer, C. U., Hvidberg, C. D., Dahl-Jensen, D., Kipfstuhl, J., and Legrand, M.: A comparison of the volcanic records over the past 4000 years from the Greenland Ice Core Project and Dye 3 Greenland ice cores, J. Geophys. Res., 102, 26707-26723, doi:10.1029/97JC00587, 1997.

Dansgaard, W. and Johnsen, S. J.: A flow model and a time scale for the ice core from Camp Century, Greenland, J. Glaciol., 8, 215-223, 1969.

Dolgova, E. A., Matskovskiy, V. V., Solomina, O. N., Rototarva, O. V., Nosenko, G. A., and Khmelevskoy, I. F.: Rekonstruktsiya balansa massy lednika Garabashi (1800-2005) po dendrokhronologicheskim dannim (Reconstructing mass balance of Grabashi Glacier (1800-2005) using dendrochronological data), Led i Sneg (Ice and Snow), 1, 34-42, doi:10.15356/2076-67342013-1-34-42, 2013 (in Russian with English summary).

Dyurgerov, M. B. and Popovnin, V. V.: Rekonstruktysiya balansa massy, prostranstvennogo polozheniya I zhidkogo stoka lednika Dhzankuat so vtoroi poloviny 19 veka (Reconstruction of mass balance, spatial position, and liquid discharge of Dzhankuat Glacier since the second half of the 19th century), Materialy glyatsiologicheskikh issledovanii (Data Glaciol. Stud.), 40, 111126, 1988 (in Russian with English summary).

Eichler, A., Tinner, W., Brusch, S., Olivier, S., Papina, T., and Schwikowski, M.: An ice-core based history of Siberian forest fires since AD 1250, Quaternary Sci. Rev., 30, 1027-1034, doi:10.1016/j.quascirev.2011.02.007, 2011.

Fagerli, H., Legrand, M., Preunkert, S., Vestreng, V., Simpson, D., and Cerquera, M.: Modeling historical long-term trends of sulfate, ammonium, and elemental carbon over Europe: a comparison with ice core records in the Alps, J. Geophys. Res., 112, D23S13, doi:10.1029/2006JD008044, 2007.

Ginot, P., Schotterer, U., Stichler, W., Godoi, M. A., Francou, B., and Schwikowski, M.: Influence of the Tungurahua eruption on the ice core records of Chimborazo, Ecuador, The Cryosphere, 4, 561-568, doi:10.5194/tc-4-561-2010, 2010. 
Golubev, G. N., Dyurgerov, M. B., Markin, V. A., Berry, B. L., Sukhanov, L. A., Zolotarev, E. A., Danilina, A. V., and Arutunov, Y. G.: Lednik Dzhankuat (Tsentralniy Kavkaz) (Water-ice and heat balances of Jankuat Glacier (Central Caucasus)), edited by: Byarski, I. Y., Hydrometeoizdat Press, Leningrad, 184 pp., 1978 (in Russian with English summary).

Golubev, V. N., Mikhalenko, V. N., Serebrennikov, A. V., and Gvozdik, O. A.: Strukturnie issledovaniya ledyanogo kerna Dzhantuganskogo firnovogo plato na Tsentralnom Kavkaze (Structural studies of the ice core obtained from the Djantugan Firn Plateauin the Central Caucasus), Materialy glyatsiologicheskikh issledovanii (Data Glaciol. Stud.), 64, 25-33, 1988 (in Russian with English summary).

Hörhold, M. W., Kipfstuhl, S., Wilhelms, F., Freitag, J., and Frenzel, A.: The densification of layered polar firn, J. Geophys. Res., 116, F01001, doi:10.1029/2009JF001630, 2011.

Hou, S., Chappellaz, J., Raynaud, D., Masson-Delmotte, V., Jouzel, J., Bousquet, P., and Hauglustaine, D.: A new Himalayan ice core $\mathrm{CH}_{4}$ record: possible hints at the preindustrial latitudinal gradient, Clim. Past, 9, 2549-2554, doi:10.5194/cp-9-2549-2013, 2013.

Johnsen, S., Clausen, H. B., Cuffey, K. M., Hoffmann, G., Schwander, J., and Creyts, T.: Diffusion of stable isotopes in polar firn and ice: the isotope effect in firn diffusion, in: Physics of Ice Core Records, edited by: Hondoh, T., Hokkaido University Press, Sapporo, 121-140, 2000.

Kawamura, K., Izawa, Y., Mochida, M., and Shiraiwa, T.: Ice core records of biomass burning tracers (levoglucosan and dehydroabietic, vanillic and p-hydroxybenzoic acids) and total organic carbon for past 300 years in the Kamchatka Peninsula, Northeast Asia, Geochim. Cosmochim. Ac., 99, 317-329, doi:10.1016/j.gca.2012.08.006, 2012.

Kerimov, A. M., Rototaeva, O. V., and Khmelevskoy, I. F.: Raspredelenie tyazhelikh metallov v poverkhnostnikh sloyakh snezhnofirnovoi tolschi na yuzhnom sklone Elbrusa (Distribution of heavy metals in the surface layers of snow-firn mass on the southern slope of Mount Elbrus), Led i Sneg (Ice and Snow), 2, 24-34, 2011 (in Russian with English summary).

Kotlyakov, V. M., Arkhipov, S. M., Henderson, K. A., and Nagornov, O. V.: Deep drilling of glaciers in Eurasian Arctic as a source of paleoclimatic records, Quaternary Sci. Rev., 23, 1371-1390, doi:10.1016/j.quascirev.2003.12.013, 2004.

Kovalev, P. V.: Sovremennoe oledenenie basseina reki Baksan (Recent glaciation of the Baksan River basin), Materialy Kavkazskoi ekspeditsii po programme Mezhdunarodnogo geofizicheskogo goda (Proceedings of the IGY Caucasus expedition), 2, 3-106, 1961 (in Russian).

Krenke, A. N., Menshutin, V. V., Voloshina, A. P., Panov, V. D., Bazhev, A. B., Bazheva, V. J., Balaeva, V. A., Vinogradov, O. N., Voronina, L. S., Garelik. I. S., Davidovich, N. V., Dubinskaya, N. M., Macheret, Y. Y., Moiseeva, G. P., Psareva, T. V., Tyulina, T. Y., Freidlin, V. S., Khmelevskoy, I. F., Chernova, L. P., and Shadrina, O. V.: Lednik Marukh (Zapadniy Kavkaz) (Marukh Glacier (Western Caucasus)), edited by: Kotlyakov, V. M., Hydrometeoizdat Press, Leningrad, 254, 1988 (in Russian with English summary).

Kutuzov, S., Lavrentiev, I. I., Macheret, Y. Y., and Petrakov, D. A.: Izmenenie lednika Marukh s 1945 po 2011 (Changes of Marukh Glacier from 1945 to 2011), Led i Sneg (Ice and Snow), 1, 123-
127, doi:10.15356/2076-6734-2012-1-123-127, 2012 (in Russian).

Kutuzov, S., Shahgedanova, M., Mikhalenko, V., Ginot, P., Lavrentiev, I., and Kemp, S.: High-resolution provenance of desert dust deposited on Mt. Elbrus, Caucasus in 2009-2012 using snow pit and firn core records, The Cryosphere, 7, 1481-1498, doi:10.5194/tc-7-1481-2013, 2013.

Kutuzov, S. S., Lavrentiev, I. I., Vasilenko, E. V., Macheret, Y. Y., Petrakov, D. A., and Popov, G. V.: Otsenka obiema lednikov Bolshogo Kavkaza po dannym radiozondirovania i modelirovania (Estimation of the Greater Caucasus glaciers volume, using radio-echo sounding data and modelling), Kriosfera Zemli (Earth Cryosphere), 1, 78-88, 2015 (in Russian with English summary).

Laverov, N. P., Dobretsov, N. L., Bogatikov, O. A., Bondur, V. G., Gurbanov, A. G., Karamurzov, B. S., Kovalenko, V. I., Melekestsev, I, V., Nechaev, Yu. V., Ponomareva, V. V., Rogozhin, E. A., Sobisevich, A. L., Sobisevich, L. E., Fodotov, S. A., Khrenov, A. P., and Yarmolyuk, V. V.: Noveyshiy i sovremenniy vulkanizm na territorii Rossii (Modern and Holocene Volcanism in Russia), Nauka, Moscow, 604 pp., 2005 (in Russian with English summary).

Lavrentiev, I. I., Mikhalenko, V. N., and Kutuzov, S. S.: Tolschina l'da i podledniy relief Zapadnogo lednikovogo plato Elbrusa (Ice thickness and subglacial relief of the Western Ice Plateau of Elbrus), Led i Sneg (Ice and Snow), 2, 12-18, 2010 (in Russian with English summary).

Legrand, M. and Mayewski, P.: Glaciochemistry of polar ice cores: a review, Rev. Geophys., 35, 219-243, doi:10.1029/96RG03527, 1997.

Legrand, M., Hammer, C., De Angelis, M., Savarino, J., Delmas, R., Clausen, H., and Johnson, S. J.: Sulphur containing species (MSA and $\mathrm{SO}_{4}$ ) over the last climatic cycle in the GRIP (central Greenland) ice core, J. Geophys. Res., 102, 26663-26679, doi:10.1029/97JC01436, 1997.

Legrand, M., Preunkert, S., Schock, M., Cerqueira, M., KasperGiebl, A., Afonso, J., Pio, C., Gelencsér, A., and DombrowskiEtchevers, I.: Major 20th century changes of carbonaceous aerosol components (EC, WinOC, DOC, HULIS, carboxylic acids, and cellulose) derived from Alpine ice cores, J. Geophys. Res., 112, D23S11, doi:10.1029/2006JD008080, 2007a.

Legrand, M., Preunkert, S., Oliveira, T., Pio, C. A., Hammer, S., Gelencsér, A., Kasper-Giebl, A., and Laj, P.: Origin of $\mathrm{C}_{2}-\mathrm{C}_{5}$ dicarboxylic acids in the European atmosphere inferred from yearround aerosol study conducted at a west-east transect, J. Geophys. Res., 112, D23S07, doi:10.1029/2006JD008019, $2007 \mathrm{~b}$.

Ligtenberg, S. R. M., Helsen, M. M., and van den Broeke, M. R.: An improved semi-empirical model for the densification of Antarctic firn, The Cryosphere, 5, 809-819, doi:10.5194/tc-5-809-2011, 2011.

Looyenga, M.: Dielectric constant of heterogeneous mixtures, Physica, 31, 401-406, doi:10.1016/0031-8914(65)90045-5, 1965.

Macheret, Y. Y.: Radiozondirovanie lednikov (Radio-Echo Sounding of Glaciers), Scientific World Publishers, Moscow, 392 pp. 2006 (in Russian with English summary).

Maeno, N. and Ebinuma, T.: Pressure sintering of ice and its implication to the densification of snow at polar glaciers and ice sheets, J. Phys. Chem., 87, 4103-4110, doi:10.1021/j100244a023, 1983. 
Matyukhin, G. D.: Klimaticheskie dannie po vysotnim poyasam yuzhnogo sklona Elbrusa (Climatic data for the southern slope of Elbrus), in: Informatsionniy sbornik o rabotakh Geograficheskogo fakul'teta Moskovskogo gosudarstvennogo universiteta po Mezhdunarodnomu geofizicheskomu godu (Information collection on the investigation of the Faculty of Geography, Moscow State University for the International Geophysical Year), 5. Moscow, Faculty of Geography, Moscow State University, 130-194, 1960 (in Russian).

Mätzler, C. and Wegmüller, U.: Dielectric properties of fresh-water ice at microwave frequencies, J. Phys. D Appl. Phys., 20, 16231630, doi:10.1088/0022-3727/20/12/013, 1987.

Mikhalenko, V. N.: Glubinnoe stroenie lednikov tropicheskikh I umerennikh shirot (Inner Structure of Glaciers in Non-Polar Regions), LKI Publishers, Moscow, 320 pp., 2008 (in Russian with English summary).

Mikhalenko, V. N.: Glubokoe burenie l'la bliz vershiny Elbrusa (Deep ice core drilling near summit of Mt. Elbrus), Led i Sneg (Ice and Snow), 1, 123-126, 2010 (in Russian with English summary).

Mikhalenko, V. N., Kuruzov, S. S., Lavrentiev, I. I., Kunakhovich, M. G., and Thompson, L. G.: Issledovanie zapadnogo lednikovogo plato Elbrusa: rezultaty i perspektivy (Western Elbrus Plateau studies: results and perspectives), Materialy glyatsiologicheskikh issledovanii (Data Glaciol. Stud.), 99, 185-190, 2005 (in Russian with English summary).

Mushketov, I. V.: Geologicheskaya ekskursia na Kavkaz v 1881 (Geological excursion to Caucasus in 1881), Izvestiya Imperatorskogo Russkogo geografichaskogo obschestva (Proceedings of the Russian Geographical Society), 18, 112-138, 1882 (in Russian).

Nosenko, G. A., Khromova, T. E., Rototaeva, O. V., and Shahgedanova, M.: Reaktsiya lednikov Tsentralnogo Kavkaza v 2001-2010 na izmeneniya temperatury I kolichestva osadkov (Glacier reaction to temperature and precipitation change in Central Caucasus), 2001-2010, Led i Sneg (Ice and Snow), 1, 26-33, doi:10.15356/2076-6734-2013-1-26-33, 2013 (in Russian with English summary).

Pastukhov, A. V.: Poseschenie Elbrusa 13 Iyulya 1890 (Ascending to Elbrus on 13 July 1890), Izvestiya Kavkazskogo otdela Imteratorskogo Russkogo geograficheskogo obschestva (Proceedings of the Caucasus Branch the Russian Imperial Geographical Society), 15, 22-37, 1893 (in Russian).

Podozerski, K. I.: Ledniki Kavkazskogo khrebta (Glaciers of the Caucasus Range), Izvestiya Kavkazskogo otdela Imperatorskogo Russkogo geograficheskogo obshchestva (Proceedings of the Caucasus Branch the Russian Imperial Geographical Society), 29, 200 pp., 1911 (in Russian).

Preunkert, S. and Legrand, M.: Towards a quasi-complete reconstruction of past atmospheric aerosol load and composition (organic and inorganic) over Europe since 1920 inferred from Alpine ice cores, Clim. Past, 9, 1403-1416, doi:10.5194/cp-91403-2013, 2013.

Preunkert, S., Wagenbach, D., Legrand, M., and Vincent, C.: Col du Dôme (Mt. Blanc Massif, French Alps) suitability for ice-core studies in relation with past atmospheric chemistry over Europe, Tellus B, 52, 993-1012, doi:10.1034/j.1600-0889.2000.d01-8.x, 2000.
Psareva, T. V.: Preobrazovanie snezhno-firnovoi tolschi I typi l'doobrazovaniya na El'bruse (Transformation of snow-firn layer and types of ice formation on Elbrus), Materialy glyatsiologicheskikh issledovanii (Data Glaciol. Stud.), 10, 79-86, 1964 (in Russian with English summary).

Rototaeva, O. V. and Tarasova, L. N.: Rekonstruktsiya balansa massi lednika Garabashi za poslednee stoletie (Reconstruction of the Garabashi Glacier mass balance in the last century), Materialy glyatsiologicheskikh issledovanii (Data Glaciol. Stud.), 88, 16-26, 2000 (in Russian with English summary).

Rototaeva, O. V., Nosenko, G. A., Tarasova, L. N., and Khmelevskoy, I. F.: Obschaya kharakteristika oledeneniya severnogo sklona Bolshogo Kavkaza (General characteristics of glacierization of the north slope of the Gteater Caucasus), in: Sovremennoe oledenenie Severnoi i Tsentralnoi Evrazii (Glaciation in North and Central Eurasia at Present Time), edited by: Kotlakov, V. M., Nauka Press, Moscow, 141-144, 2006 (in Russian).

Salamatin, A. N., Murav'yev, Y. D., Shiraiwa, T., and Matsuoka, K.: Modelling dynamics of glaciers in volcanic cratrs, J. Glaciol., 46, 177-187, doi:10.3189/172756500781832990, 2000.

Salamatin, A. N., Shiraiwa, T., Muravyev, Y. D., Kameda, T., Silantiyeva, E., and Ziganshin, M.: Dynamics and borehole temperature memory of Gorshkov Ice Cap on the summit of Ushkovsky Volcano, Kamchtka Peninsula, Proceedings of the International Symposium on the Atmosphere-Ocean-Cryosphere Interaction in the Sea of Okhotsk and the Surrounding Environments held at Institute of Low Temperature Science, Hokkaido University, Sapporo, Japan, 12-15 December 2000, 120-121, 2001.

Salamatin, A. N., Lipenkov, V. Y., Barnola, J.-M., Hori, A., Duval, P., and Hondoh, T.: Snow/firn densification in polar ice sheets, in: Physics of Ice Core Records II: Papers Collected After the 2nd International Workshop on Physics of Ice Core Records, held in Sapporo, Japan, 2-6 February 2007 (Low Temperature Science; 68(Suppl.)), edited by: Hondoh, T., Institute of Low Temperature Science, Hokkaido University, Sapporo, 195-222, 2009.

Sato, T., Shiraiwa, T., Greve, R., Seddik, H., Edelmann, E., and Zwinger, T.: Accumulation reconstruction and water isotope analysis for 1736-1997 of an ice core from the Ushkovsky volcano, Kamchatka, and their relationships to North Pacific climate records, Clim. Past, 10, 393-404, doi:10.5194/cp-10-393-2014, 2014.

Schwikowski, M.: Reconstruction of European air pollution from Alpine ice cores, in: Earth Paleoenvironments: Records Preserved in Mid- and Low-Latitude Glaciers, edited by: Cecil, L., De, W., Green, J. R., and Thompson, L. G., Kluwer Academic Publishers, Dordrecht, Developments in Paleoenvironmental Research, 9, 95-119, doi:10.1007/1-4020-2146-1_6, 2004.

Serebryannyi, L. R., Golodkovskaya, N. A., Orlov, A. V., Malyasova, E. S., and Il'ves, E. O.: Kolebaniya lednikov i protsessy morenonakopleniya na Tsentral'nom Kavkaze (Glacier variations and moraine accumulation: processes in Central Caucasus), Nauka, Moscow, 216 pp., 1984 (in Russian with English summary).

Shahgedanova, M., Kutuzov, S., White, K. H., and Nosenko, G.: Using the significant dust deposition event on the glaciers of Mt. Elbrus, Caucasus Mountains, Russia on 5 May 2009 to develop a method for dating and "provenancing" of desert dust events 
recorded in snow pack, Atmos. Chem. Phys., 13, 1797-1808, doi:10.5194/acp-13-1797-2013, 2013.

Shahgedanova, M., Nosenko, G., Kutuzov, S., Rototaeva, O., and Khromova, T.: Deglaciation of the Caucasus Mountains, Russia/Georgia, in the 21 st century observed with ASTER satellite imagery and aerial photography, The Cryosphere, 8, 2367-2379, doi:10.5194/tc-8-2367-2014, 2014.

Solomina, O. N., Dolgova, E. A., and Maximova, O. E.: Rekonstruktsiya gidrometeorologicheskikh usloviy poslednikh stoletiy na severnom Kavkaze, v Krymu i na Tien Shane po dendrokhronologicheskim dannim (Tree-Ring Based Hydrometeorological Reconstructions in Crimea, Caucasus and Tien-Shan), Nestor History Press, Moscow, St. Petersburg, 232 pp., 2012 (in Russian with English summary).

Solomina, O. N., Kalugin, I. A., Aleksandrin, M. Y., Bushueva, I. S., Darin, A. V., Dolgova, E. A., Jomelli, V., Ivanov, M. N., Matskovsky, V. V., Ovchinnikov, D. V., Pavlova, I. O., Razumovsky, L. V., and Chepurnaya, A. A.: Burenie osadkov ozera Kara-Kel' (dolina reki Teberdy) I perspektivy rekonstruktsii istorii oledeneniya i klamata golotsena na Kavkaze (Coring of Karakel' Lake sediments (Teberda River valley) and prospects for reconstruction of glaciation and Holocene climate history in the Caucasus), Led i Sneg (Ice and Snow), 2, 102111, doi:10.15356/2076-6734-2013-2-102-111, 2013 (in Russian with English summary).

Stokes, C. R., Gurney, S. D., Shahgedanova, M., and Popovnin, V.: Late-20th-century changes in glacier extent in the Caucasus Mountains, Russia/Georgia, J. Glaciol., 52, 99-109, doi:10.3189/172756506781828827, 2006.

Takeuchi, N., Takahashi, A., Uetake, J., Yamazaki, T., Aizen, V. B., Joswiak, D., Surazakov, A., and Nikitin, S.: A report on ice core drilling on the western plateau of Mt. Belukha in the Russian Altai Mountains in 2003, Polar Meteorology and Glaciology, 18, 121-133, 2004.

Thompson, L. G.: Understanding Global Climate Change: Paleoclimate Perspective from the World's Highest Mountains, P. Am. Philos. Soc., 154, 133-157, 2010.

Troshkina, E. S.: Stratigragiya snazhno-firnovogo pokrova v oblasti pitaniya (Snow and firn stratigraphy in the accumulation area of the Mt. Elbrus), in: Oledenenie Elbrusa (Elbrus Glaciers), edited by: Tushinski, G. K., Moscow University Press, Moscow, 213222, 1968 (in Russian).

Tushinskii, G. K. (Ed.): Oledenenie El'brusa (Glaciation of the Elbrus Mountain), Moscow University Press, Moscow, 346 pp., 1968 (in Russian).

Vasilenko, E. V., Sokolov, V. A., Macheret, Y., Glazovsky, A. F., Cuadrado, M. L., and Navarro, F. J.: A digital recording system for radioglaciological studies, Royal Society of New Zealand, Bulletin, 35, 611-617, 2002.
Vasilenko, E. V., Glazovsky, A. F., Macheret, Y. Y., Navarro, F., Sokolov, V. G., and Shiraiwa, T.: Georadar VIRL dlya zondirovaniya lednikov (Georadar VIRL for glacier sounding), Materialy glyatsiologicheskikh issledovanii (Data Glaciol. Stud.), 94, 225-234, 2003 (in Russian with English summary).

Vaughan, D. G., Comiso, J. C., Allison, I., Carrasco, J., Kaser, G., Kwok, R., Mote, P., Murray, T., Paul, F., Ren, J., Rignot, E., Solomina, O., Steffen, K., and Zhang, T.: Observations: cryosphere, in: Climate Change 2013: The Physical Science Basis, Contribution of Working Group I to the Fifth Assessment Report of the Intergovernmental Panel on Climate Change, edited by: Stocker, T. F., Qin, D., Plattner, G.-K., Tignor, M., Allen, S. K., Boschung, J., Nauels, A., Xia, Y., Bex, V., and Midgley, P. M., Cambridge University Press, Cambridge, UK, New York, NY, USA, 2013.

Vimeux, F., Ginot, P., Schwikowski, M., Vuille, M., Hoffmann, G., Thompson, L. G., and Schotterer, U.: Climate variability during the last 1000 years inferred from Andean ice cores: a review of methodology and recent results, Palaeogeogr. Palaeocl., 281, 229-241, doi:10.1016/j.palaeo.2008.03.054, 2009.

Volodicheva, N.: The Caucasus, in: The Physical Geography of Northern Eurasia, edited by: Shahgedanova, M., Oxford University Press, Oxford, 350-376, 2002.

Werner, M., Mikolajewicz, U., Heimann, M., and Hoffmann, G.: Borehole versus isotope temperatures on Greenland: seasonality does matter, Geophys. Res. Lett., 27, 723-726, doi:10.1029/1999GL006075, 2000.

Zagorodnov, V. S., Arkhipov, S. M., Bazhev, A. B., Vostokova, T. A., Korolev, P. A., Rototaeva, O. V., Sinkevich, S. A., and Khmelevskoy, I. F.: Stroenie, sostav i gidrotermichaskiy rezhim lednika Garabashi na Elbruse (Structure, state and hydrothermal regime of the Garabashi Glacier), the Elbrus area, Materialy glyatsiologicheskikh issledovanii (Data Glaciol. Stud.), 73, 109-117, 1992 (in Russian with English summary).

Zagorodnov, V. S., Nagornov, O. V., and Thompson, L. G.: 2006, influence of air temperature on a glacier's active-layer temperature, Ann. Glaciol., 43, 285-287, doi:10.3189/172756406781812203, 2006.

Zolotarev, E. A. and Khar'kovets, E. G.: Oledenenie Elbrusa v kontse XX veka: tsifrovaya ortofotokarta Elbrusa na 1997 (Glaciation of Elbrus at the end of XX century (digital orthophotomap of Elbrus for 1997)), Materialy glyatsiologicheskikh issledovanii (Data Glaciol. Stud.), 89, 175-191, 2000 (in Russian with English summary).

Zolotarev, E. A. and Khar'kovets, E. G.: Evolutsiya oledeneniya Elbrusa posle malogo lednikovogo perioda (Development of glaciers of Mount Elbrus after the Little Ice Age), Led i Sneg (Ice and Snow), 2, 15-22, 2012 (in Russian with English summary). 